Prepared for the U.S. Department of Energy

under Contract DE-AC05-76RL01830

\title{
Visual Modeling for Aqua Ventus I off Monhegan Island, ME
}

Luke Hanna

Jonathan Whiting

Andrea Copping

November 2013

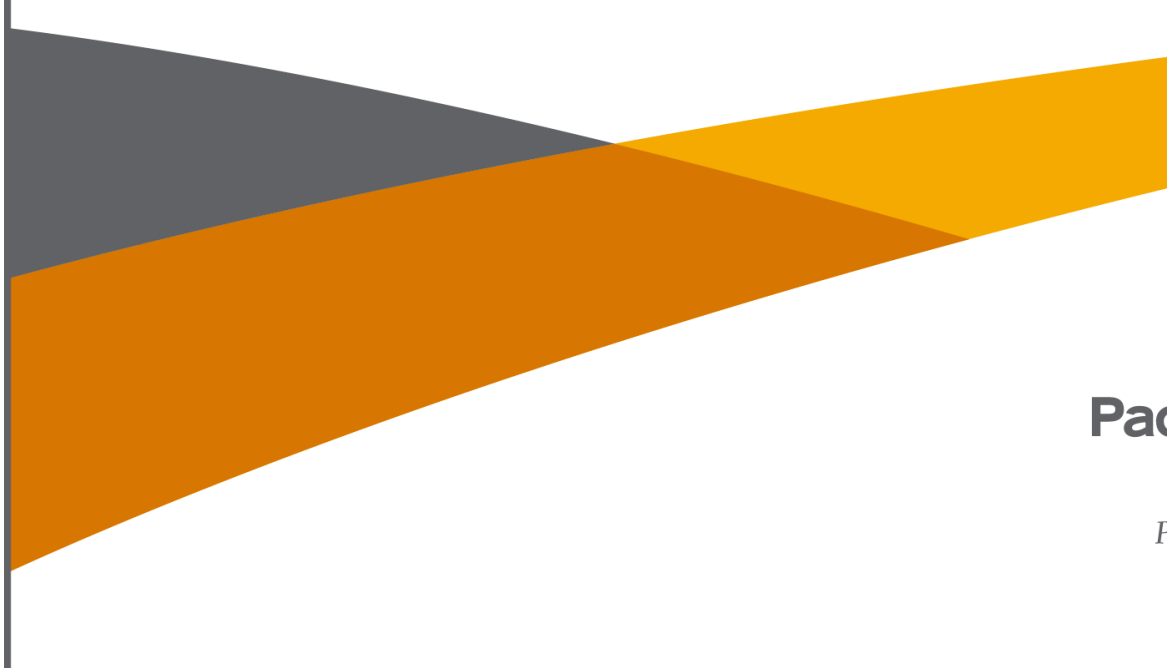




\title{
DISCI AAIMER
}

This report was prepared as an account of work sponsored by an agency of the United States Government. Neither the United States Government nor any agency thereof, nor Battelle Memorial Institute, nor any of their employees, makes any warranty, express or implied, or assumes any legal liability or responsibility for the accuracy, completeness, or usefulness of any information, apparatus, product, or process disclosed, or represents that its use would not infringe privately owned rights. Reference herein to any specific commercial product, process, or service by trade name, trademark, manufacturer, or otherwise does not necessarily constitute or imply its endorsement, recommendation, or favoring by the United States Government or any agency thereof; or Battelle Memorial Institute. The views and opinions of authors expressed herein do not necessarily state or reflect those of the United States Government or any agency thereof.

\author{
PACIFIC NORIHWEST NATIONAL LABORATORY \\ operated by \\ BATTELLE \\ for the \\ UNITED STATES DEPARTMENT OF ENERGY \\ under Contract DE-AC05-76RL01830
}

Printed in the United States of America

$\Lambda$ vailable to DOE and DOE contractors from the

Office of Scientific and Technical Information,

P.O. Box 62, Oak Ridge, TN 37831-0062;

ph: (865) 576-8401

fax: $(865) 576-5728$

email: reports $(\hat{a})$ adonis.osti.gov

\author{
Available to the public from the National Technical Information Service, \\ U.S. Department of Commerce, 5285 Port Royal Rd., Springfield, VA 22161 \\ ph: (800) 553-6847 \\ fax: (703) 605-6900 \\ email: orders $(a)$ tis.fedworld.gov \\ online ordering: http://www.ntis.gov/ordering.htm
}

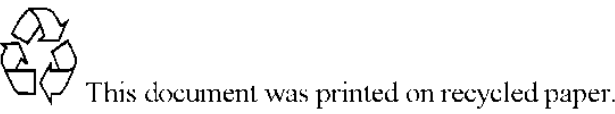

$(9 / 2003)$ 


\section{Visual Modeling for Aqua Ventus I off Monhegan Island, ME}

Luke Hanna

Jonathan Whiting

Andrea Copping

November 2013

Prepared for

the U.S. Department of Energy

under Contract DE-AC05-76RL01830

Pacific Northwest National Laboratory

Seattle Washington 98109 
PNNL-22982

\section{Table of Contents}

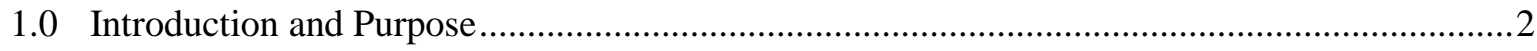

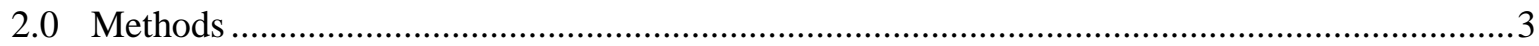

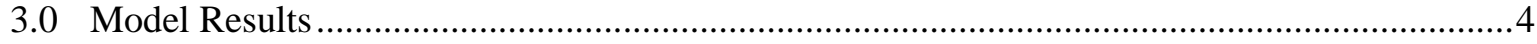

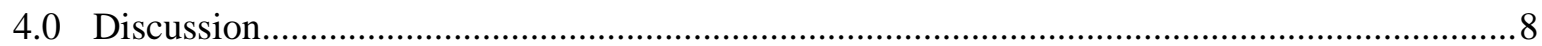

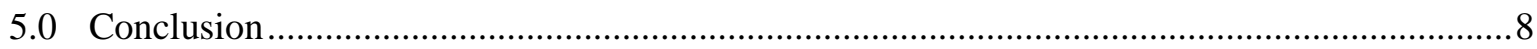

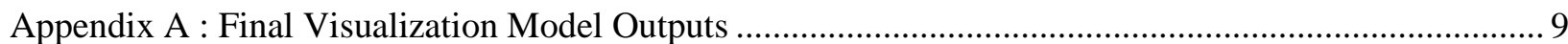


PNNL-22982

\subsection{Introduction and Purpose}

The DeepCwind consortium, led by the University of Maine, was awarded funding under the US Department of Energy's (DOE) Offshore Wind Advanced Technology Demonstration Program to develop two floating offshore wind turbines in the Gulf of Maine equipped with Goldwind 6 MW direct drive turbines, as the Aqua Ventus I project. The turbines will be deployed in the state waters of Maine, approximately 2.9 miles off Monhegan Island; Monhegan Island is located roughly 10 miles off the coast of Maine. As part of the funding agreement through DOE, the Aqua Ventus I project will be evaluated along with six other offshore wind projects within the first year to determine where future development has the highest probability of commercial viability. To ensure the Aqua Ventus I project makes this down select, significant progress must be made to demonstrate to DOE that the Aqua Ventus I project has both a feasible pathway to a competitive cost of energy and has illustrated a clear and realistic path to regulatory compliance and project completion.

To assist the University of Maine in demonstrating a clear pathway to project completion, PNNL has developed visualization models of the Aqua Ventus I project that accurately depict the Aqua Ventus I turbines from various points on Monhegan Island, and the surrounding area. With a hub height of 100 meters, the Aqua Ventus I turbines are large and may be seen from many areas on Monhegan Island, potentially disrupting important viewsheds. By developing these visualization models, which make use of photographs of the viewshed taken from Monhegan Island and the surrounding area with the Aqua Ventus I turbines superimposed within each photograph, PNNL intends to support the project's siting and permitting process by providing the Monhegan Island community and various other stakeholders with a probable glimpse of how the Aqua Ventus I project will appear. 
PNNL-22982

\subsection{Methods}

Pacific Northwest National Laboratory (PNNL) used the WindPRO 2.9 Photomontage software to generate visual model outputs of the Aqua Ventus I floating offshore wind project. This software enables the user to input landscape images and superimpose rendered wind turbines on the image to produce a realistic visual impression of a wind farm. While the software contains an extensive database of wind turbines and their physical characteristics, it also allows for custom renderings to be entered as wind turbine components or objects superimposed on the landscape images. WindPRO also provides a zero meter line to indicate where the actual horizon is on the image. This informs the user on where the wind turbines should be positioned in reference to the horizon and is a valuable tool when dealing with an ocean scape and developing visual models for an offshore wind farm such as Aqua Ventus I.

Data required for the visualization model were gathered on Monhegan Island in June 2013, and consisted of 27 photographs from 12 strategic points along the south, southeast and eastern side of Monhegan Island. All of the 27 pictures were taken with a Sony NEX-5 camera with $18-55 \mathrm{~mm}$ lens at a $52 \mathrm{~mm}$ focal length. Latitude, longitude, elevation, general orientation, and focal length of camera lens were recorded at each of the 12 locations. In October 2013, additional data were collected by the University of Maine which included 15 photographs from 5 new locations on Monhegan Island and 5 photographs from Pemaquid Point on the mainland of Maine. The five additional photographs from Monhegan Island were taken with a Nikon D90 camera with image focal lengths ranging from 27 to $39 \mathrm{~mm}$. The photographs taken from Pemaquid Point were taken with an Apple iPhone 5 with a focal length of $35 \mathrm{~mm}$. One photograph from each of the 18 strategic locations was used to create 18 final visualization model outputs; photographs were chosen based on the quality and the focal length of images. Because the focal length affects the overall size of the rendered turbines, it was preferred to use images with a consistent or similar focal length.

The physical appearance of the Aqua Ventus I turbines was derived from the extensive WindPRO database that contains information on the physical characteristics of common wind turbines and their overall appearances from certain distances and orientations. A Siemens $6 \mathrm{MW}$ turbine was selected to represent the Goldwind $6 \mathrm{MW}$ turbines proposed for the Aqua Ventus I project. Once selected, these turbines were modified to have the same hub height $(100 \mathrm{~m})$ and rotor diameter $(129 \mathrm{~m})$ as the proposed Goldwind turbines. While this generated nacelles and turbine blades that were very similar to the Goldwind 6MW turbines, the proposed foundation for the Aqua Ventus I project is a floating concrete structure which is not available in the WindPRO database. To address this issue, PNNL and University of Maine created separate three dimensional renderings of the Aqua Ventus I floating wind turbine foundations in suitable file formats to be integrated directly into the WindPRO photomontage software. After comparing both renderings, although the University of Maine rendering had more detail at close range, the PNNL rendering included only the tower and the floating foundation which enabled WindPRO's photomontage software to render the nacelle and turbine blades based on the turbine's overall scale. When viewed from roughly three miles away, the PNNL rendering provided a more accurate representation of the Aqua Ventus I turbines. For the final visualization mode outputs, the overall appearance of the Aqua Ventus I turbines was altered by administering certain environmental conditions such as cloud cover and the presence of fog/haze. This not only allowed for the turbines to appear more realistic in hazy or low light conditions, but it also enabled PNNL to create night time visual models of the Aqua Ventus I turbines. 
Although the lighting requirements for floating offshore wind turbines in US waters have not yet been determined by the US Coast Guard, lighting for offshore wind turbines in the UK was used to simulate the probable illumination that will be present on the top of the Aqua Ventus 1 turbines nacelle.

To provide additional insight on how the Aqua Ventus I project may appear from Monhegan Island during the night time, the 12 images taken by PNNL were altered in Adobe Photoshop to appear as though the photographs were taken at night. These images were then reprocessed through the WindPRO Photomontage software to visualize how the Aqua Ventus I project will appear at night time with a light on top of each turbine. The image taken from Pemaquid Point was also altered in Adobe Photoshop and reprocessed through the WindPRO Photomontage software; the other five images taken by University of Maine were not altered in Adobe Photoshop because the Aqua Ventus I turbines were not visible in them and instead have arrows showing the general location of the Aqua Ventus I project.

\subsection{Model Results}

In total, one photograph from each of the 18 specific locations on Monhegan Island and the surrounding area were used to generate final visualization model outputs of the Aqua Ventus I offshore wind project. Of these 18 photographs, 13 were used to assess how the wind farm may appear during the night. The final visualization outputs for all 31 images are provided in Appendix A. Figures 1 and 2 show maps of Monhegan Island and the surrounding area with numbered markers that correspond to each of the 18 locations where photographs were taken. Information on the 18 locations and associated photographs used to generate the visualization model outputs are included in Table 1; this includes the photograph number, the photographer, location and elevation of where the picture was taken, orientation or angle of photograph, and the environmental settings such as cloud cover, fog, and visibility that were used to alter the overall appearance of the wind turbines in WindPRO. 
Table 1. Information on each visualization model output including picture number, location, description, elevation, angle of photograph, and environmental conditions used to alter the final rendering of the turbines in the final visualization model outputs.

\begin{tabular}{|c|c|c|c|c|c|c|}
\hline $\begin{array}{c}\text { Picture } \\
\quad \#\end{array}$ & Location & Description & Elevation & $\begin{array}{c}\text { Photographed } \\
\text { by }\end{array}$ & $\begin{array}{l}\text { Angle of } \\
\text { Photo }\end{array}$ & $\begin{array}{l}\text { Environmental } \\
\text { Conditions }\end{array}$ \\
\hline 1 & $43.757350^{\circ},-69.321883^{\circ}$ & Monhegan Island - Lobster Cove & $43 \mathrm{ft}$ & PNNL & $180^{\circ}, \mathrm{S}$ & Few clouds; light haze \\
\hline 2 & $43.755817^{\circ},-69.320817^{\circ}$ & Monhegan Island - Christmas Cove & $40 \mathrm{ft}$ & PNNL & $180^{\circ}, \mathrm{S}$ & Few clouds; light haze \\
\hline 3 & $43.756300^{\circ},-69.319483^{\circ}$ & $\begin{array}{l}\text { Monhegan Island - Between } \\
\text { Christmas Cove and Norton's Ledge }\end{array}$ & $80 \mathrm{ft}$ & PNNL & $180^{\circ}, \mathrm{S}$ & Few clouds; light haze \\
\hline 4 & $43.756717^{\circ},-69.316050^{\circ}$ & Monhegan Island - Norton's Ledge & $80 \mathrm{ft}$ & PNNL & $180^{\circ}, \mathrm{S}$ & Few clouds; light haze \\
\hline 5 & $43.758633^{\circ},-69.314167^{\circ}$ & $\begin{array}{l}\text { Monhegan Island - South of Burnt } \\
\text { Head }\end{array}$ & $127 \mathrm{ft}$ & PNNL & $180^{\circ}, \mathrm{S}$ & Partly cloudy; light haze \\
\hline 6 & $43.759300^{\circ},-69.313617^{\circ}$ & Monhegan Island - Burnt Head & $153 \mathrm{ft}$ & PNNL & $180^{\circ}, \mathrm{S}$ & Few clouds; light haze \\
\hline 7 & $43.760950^{\circ},-69.311167^{\circ}$ & Monhegan Island - Gull Cove & $22 \mathrm{ft}$ & PNNL & $180^{\circ}, \mathrm{S}$ & Few clouds; light haze \\
\hline 8 & $43.762683^{\circ},-69.309367^{\circ}$ & $\begin{array}{l}\text { Monhegan Island - South of White } \\
\text { Head }\end{array}$ & $130 \mathrm{ft}$ & PNNL & $180^{\circ}, \mathrm{S}$ & Few clouds; light haze \\
\hline 9 & $43.762187^{\circ},-69.309391^{\circ}$ & Monhegan Island - White Head & $140 \mathrm{ft}$ & PNNL & $180^{\circ}, \mathrm{S}$ & Few clouds; light haze \\
\hline 10 & $43.764783^{\circ},-69.306517^{\circ}$ & $\begin{array}{l}\text { Monhegan Island - Little White } \\
\text { Head }\end{array}$ & $68 \mathrm{ft}$ & PNNL & $180^{\circ}, \mathrm{S}$ & Clear sky; light haze \\
\hline 11 & $43.767883^{\circ},-69.303800^{\circ}$ & Monhegan Island - Squeakers Cove & $67 \mathrm{ft}$ & PNNL & $180^{\circ}, \mathrm{S}$ & Few clouds; fog \\
\hline 12 & $43.768750^{\circ},-69.302667^{\circ}$ & Monhegan Island - Black Head & $127 \mathrm{ft}$ & PNNL & $180^{\circ}, \mathrm{S}$ & Few clouds; fog \\
\hline 13 & $43.842778^{\circ},-69.283889^{\circ}$ & On ferry in route to Monhegan & $\mathrm{N} / \mathrm{A}^{\#}$ & $\mathrm{U}$ of $\mathrm{ME}$ & $\begin{array}{l}210^{\circ} \\
\text { S/SW }\end{array}$ & $\mathrm{N} / \mathrm{A}^{+}$ \\
\hline 14 & $43.765060^{\circ},-69.321535^{\circ}$ & $\begin{array}{l}\text { Monhegan Island - Monhegan } \\
\text { Wharf }\end{array}$ & N/A & $\mathrm{U}$ of $\mathrm{ME}$ & $\begin{array}{l}205^{\circ} \\
\text { S/SW }\end{array}$ & $\mathrm{N} / \mathrm{A}^{+}$ \\
\hline 15 & $43.764722^{\circ},-69.316111^{\circ}$ & $\begin{array}{l}\text { Monhegan Island - Monhegan } \\
\text { Lighthouse Bell }\end{array}$ & $\mathrm{N} / \mathrm{A}^{\#}$ & $\mathrm{U}$ of $\mathrm{ME}$ & $169^{\circ}, \mathrm{S} / \mathrm{SE}$ & $\mathrm{N} / \mathrm{A}^{+}$ \\
\hline 16 & $43.761944^{\circ},-69.317778^{\circ}$ & Monhegan Island - Horn Hill & $\mathrm{N} / \mathrm{A}^{\#}$ & $\mathrm{U}$ of $\mathrm{ME}$ & $160^{\circ}, \mathrm{S} / \mathrm{SE}$ & $\mathrm{N} / \mathrm{A}^{+}$ \\
\hline 17 & $43.763056^{\circ},-69.321667^{\circ}$ & Monhegan Island - Fish Beach & $\mathrm{N} / \mathrm{A}^{\#}$ & $\mathrm{U}$ of $\mathrm{ME}$ & $180^{\circ}, \mathrm{S} / \mathrm{SE}$ & $\mathrm{N} / \mathrm{A}^{+}$ \\
\hline 18 & $43.837222^{\circ},-69.506111^{\circ}$ & Mainland - Pemaquid Point & $\mathrm{N} / \mathrm{A}^{\#}$ & $\mathrm{U}$ of $\mathrm{ME}$ & $149^{\circ}, \mathrm{SE}$ & Partly cloudy; fog \\
\hline
\end{tabular}

\# : The elevation was not recorded at these locations.

${ }^{+}$: No environmental conditions were used to render the Aqua Ventus I turbines because they were not visible in these images. 
PNNL-22982

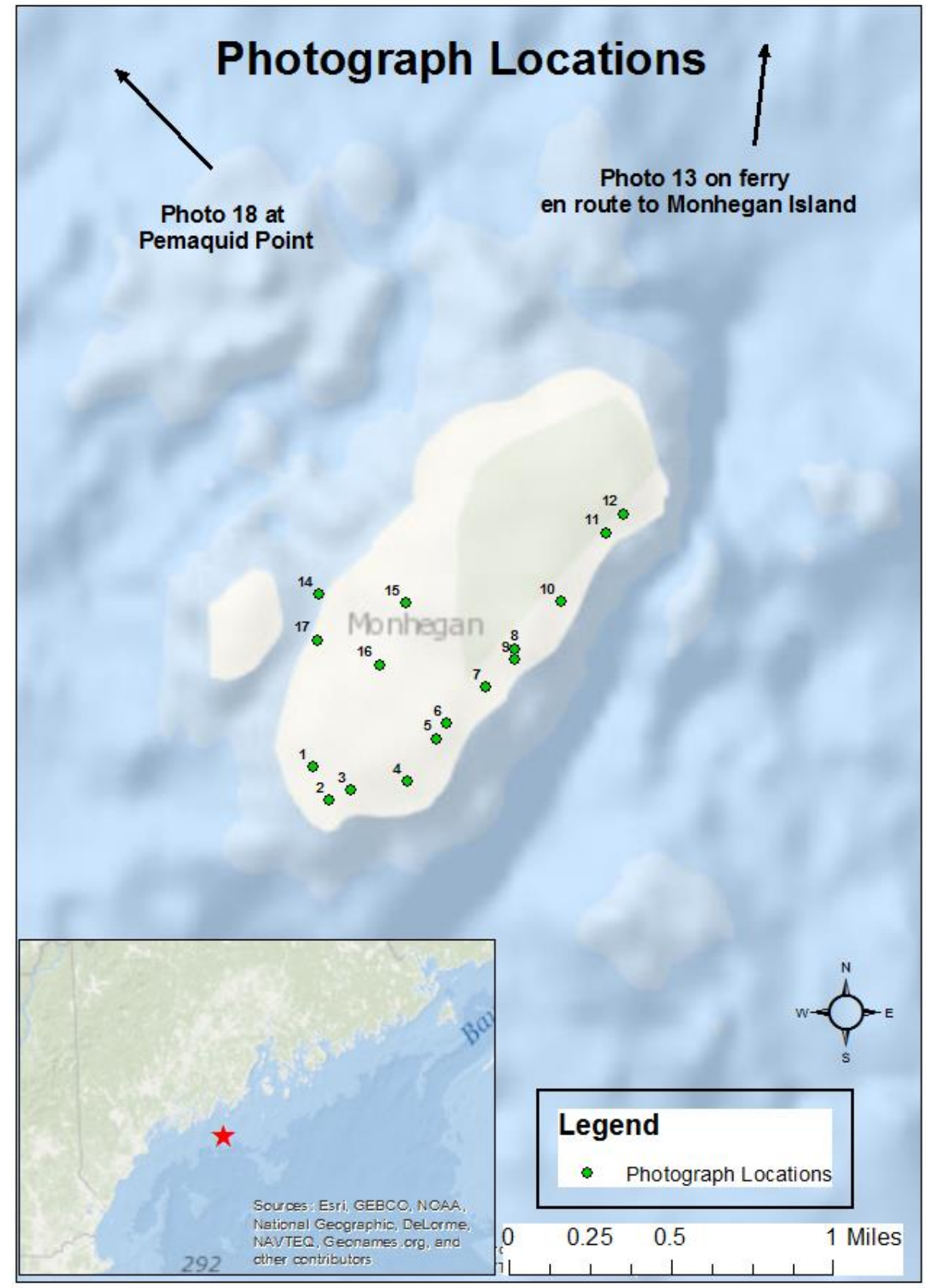

Figure 1. Map of all photograph locations on Monhegan Island. 
PNNL-22982

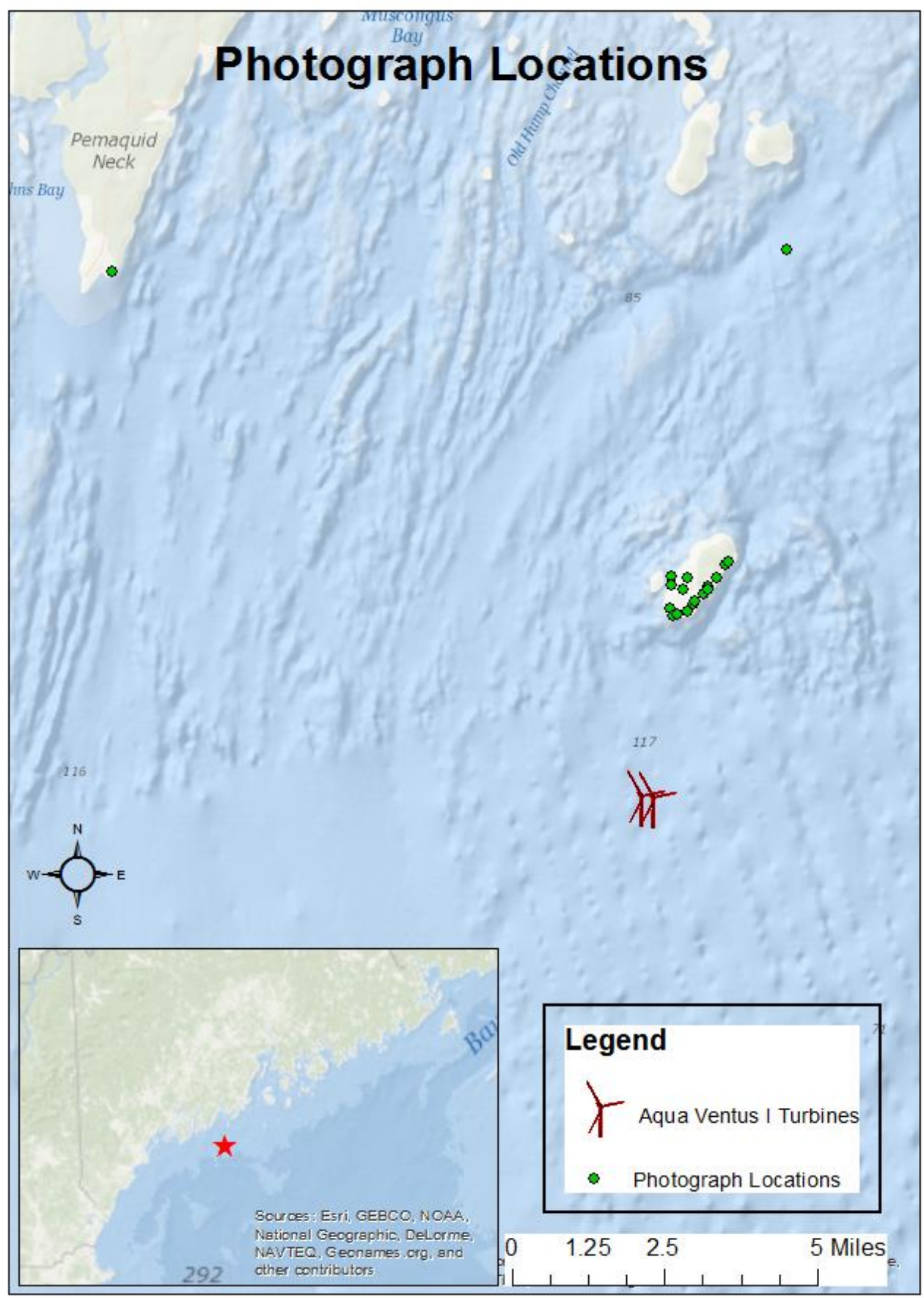

Figure 2. Map of all 18 photograph locations on Monhegan Island and the surrounding area (photograph from Pemaquid Point and location of photograph taken from the ferry en route to Monhegan Island). 
PNNL-22982

\subsection{Discussion}

By comparing the final visualization model outputs, it is apparent that the Aqua Ventus I turbines will be visible from the south and southeast shores of Monhegan Island. Depending on where an observer is located and his/her orientation, the Aqua Ventus I turbines may also be visible from other areas around Monhegan Island. However, as seen in Pictures 13-17, there are many structures such as trees and houses that can obstruct the view. From Pemaquid Point, which is roughly 12.5 miles from the proposed project site, the Aqua Ventus I turbines are located just on the horizon to the right of Monhegan Island. From this location, the turbines are small enough to where they may go unnoticed.

Depending on the environmental conditions and clarity of the night, the Aqua Ventus I turbines will probably be visible from Monhegan Island due to the flashing red aviation lights on top of each turbine. The brightness and flashing period of these lights have yet to be determined, but should be bright enough to alert any vessel or low flying aircraft to the presence of the turbines at a distance in most weather conditions. After assessing Picture 18 at night, the Aqua Ventus I turbines do not seem to be visible from Pemaquid point at night; this again will depend on the brightness of each turbine's aviation lights, which will be determined through consultations with the U.S. Coast Guard and Federal Aviation Administration.

\subsection{Conclusion}

As the Aqua Ventus I project moves forward, the visualization model outputs of the Aqua Ventus I turbines from Monhegan Island and surrounding area will be a valuable resource for educating the Monhegan community and other Maine stakeholders on how this floating offshore wind farm may appear. As more information on the exact location of the turbines becomes available, additional visualization modeling may be needed to accurately depict how the Aqua Ventus I project could appear. Furthermore, additional photographs from Monhegan Island and the surrounding area may also be beneficial in generating a more accurate depiction of the Aqua Ventus I turbines due to the different cameras used to capture the images and various focal lengths of all the images. 


\section{Appendix A: Final Visualization Model Outputs}

The following are the visualization model outputs of Aqua Ventus I from each of the 18 photograph locations. The first 18 images are day time images. The next 13 images have been altered in Adobe Photoshop to appear as though the photograph was taken at night, then reprocessed in the WindPro Photomontage software. Not all images were altered in Adobe Photoshop due to the fact that the Aqua Ventus I turbines are not visible in five of the 18 images. Each image is provided with its associated location, elevation, direction, who collected the photograph, and environmental conditions used to alter the rendered the Aqua Ventus I turbines. 


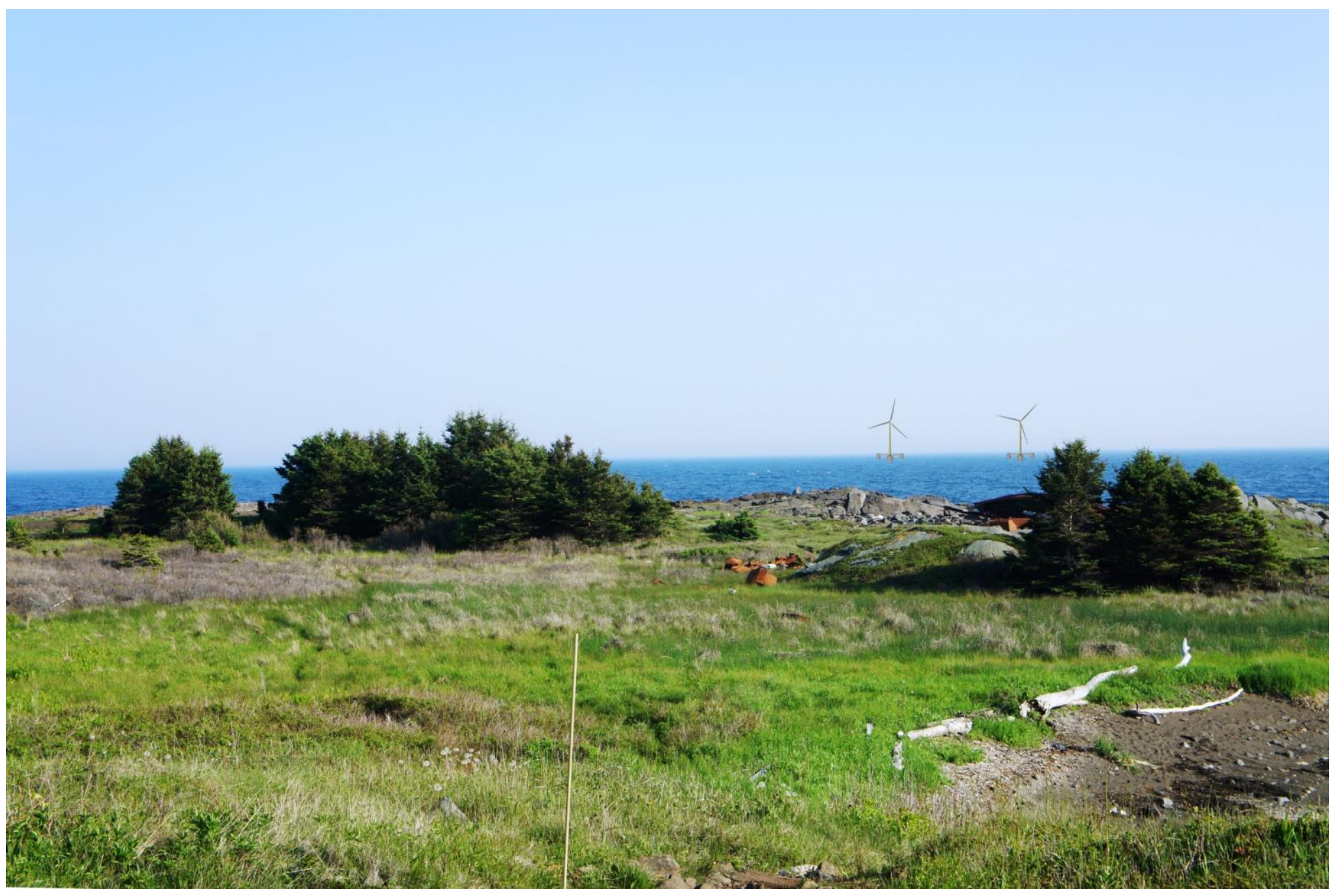

Picture 1. Taken by PNNL from Lobster Cove; $43.757350^{\circ},-69.321883^{\circ} .43 \mathrm{ft}$. elevation facing due south $\left(180^{\circ}\right)$. Environmental conditions used to render Aqua Ventus I turbines were few clouds and light haze. 


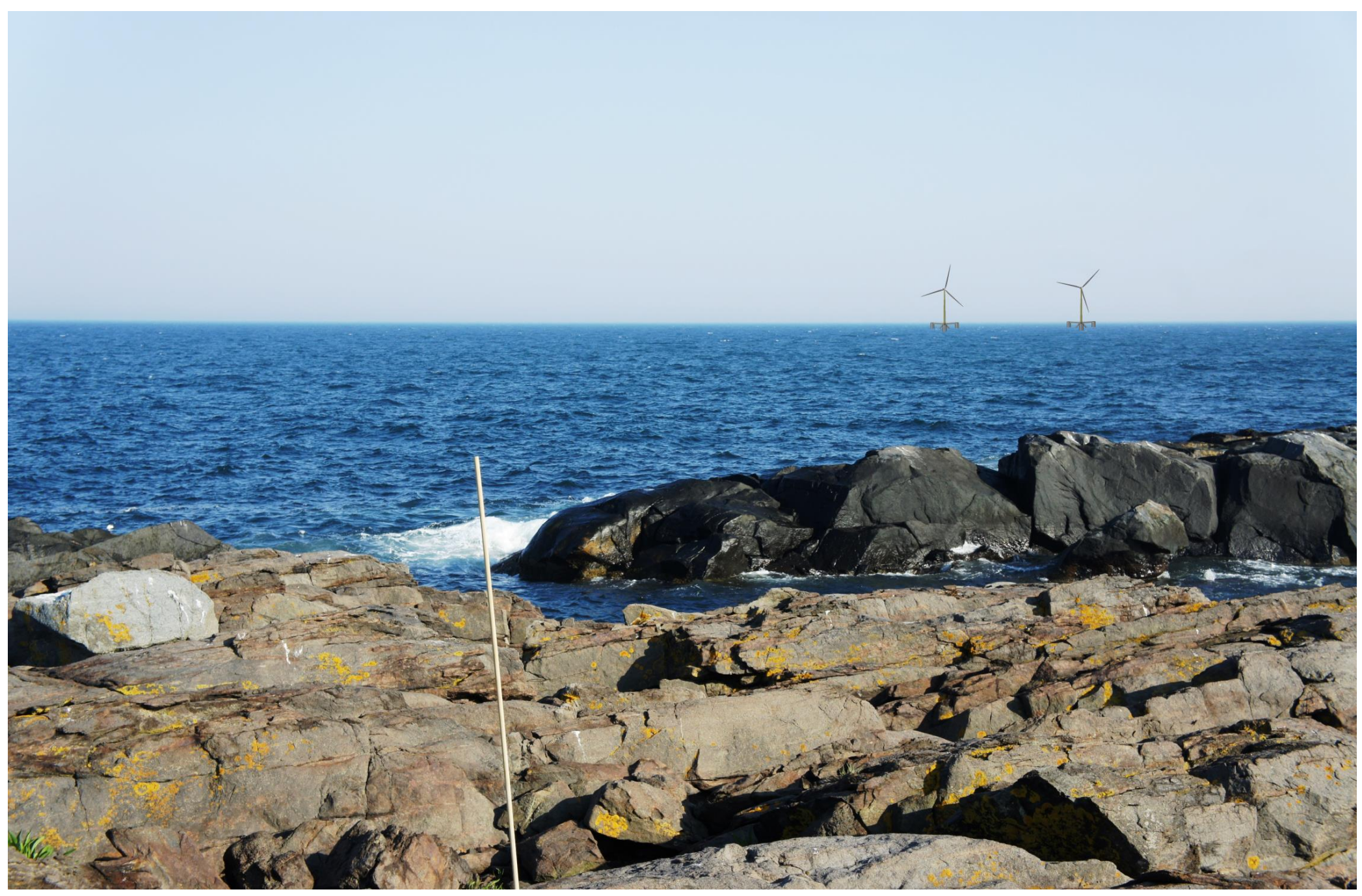

Picture 2. Taken by PNNL from Christmas Cove; $43.755817^{\circ},-69.320817^{\circ} .40 \mathrm{ft}$. elevation facing due south $\left(180^{\circ}\right)$. Environmental conditions used to render Aqua Ventus I turbines were few clouds and light haze. 


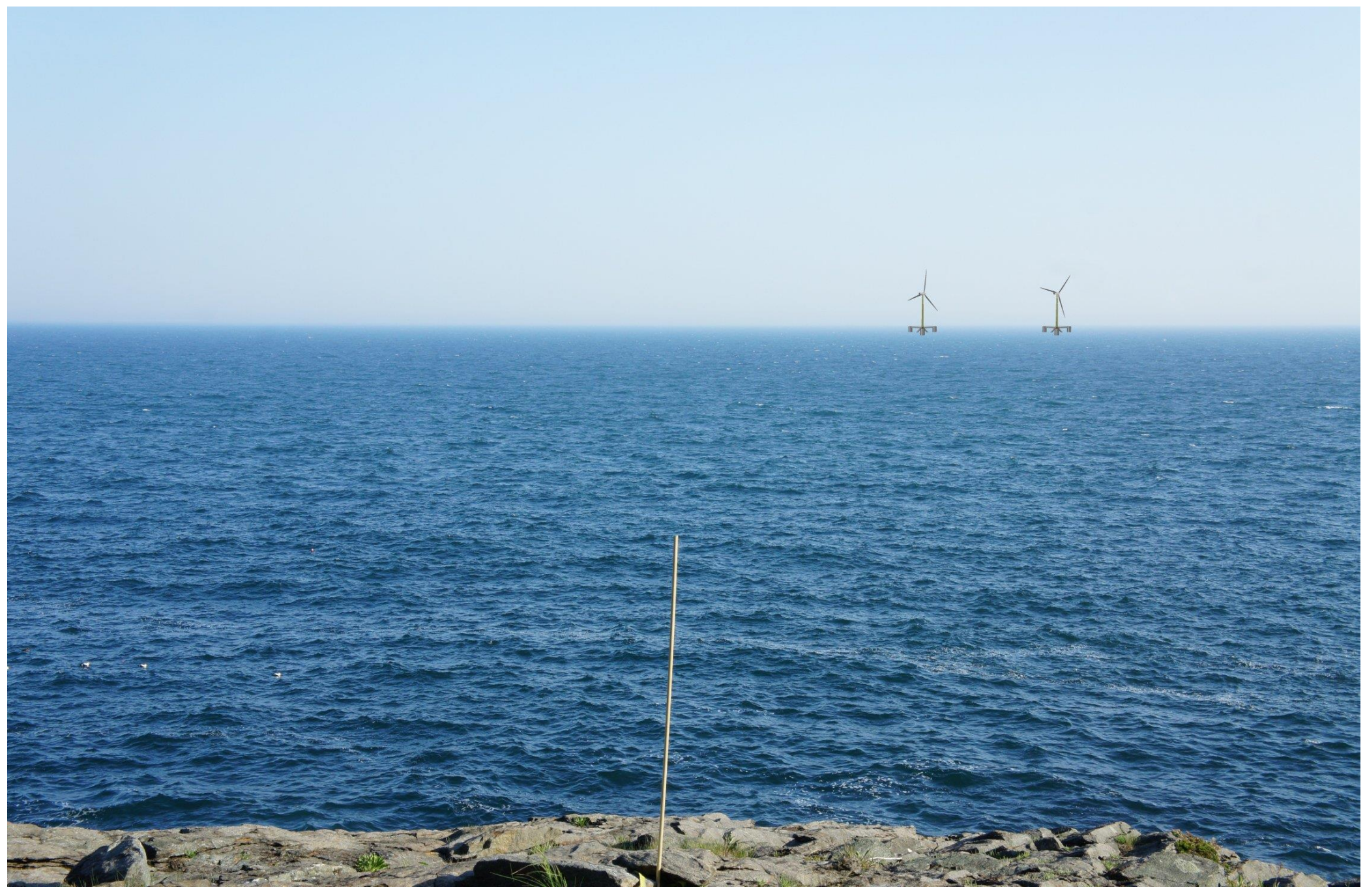

Picture 3. Taken by PNNL between Christmas Cove and Norton's Ledge; $43.756300^{\circ},-69.319483^{\circ} .80 \mathrm{ft}$. elevation facing due south $\left(180^{\circ}\right)$. Environmental conditions used to render Aqua Ventus I turbines were few clouds and light haze. 


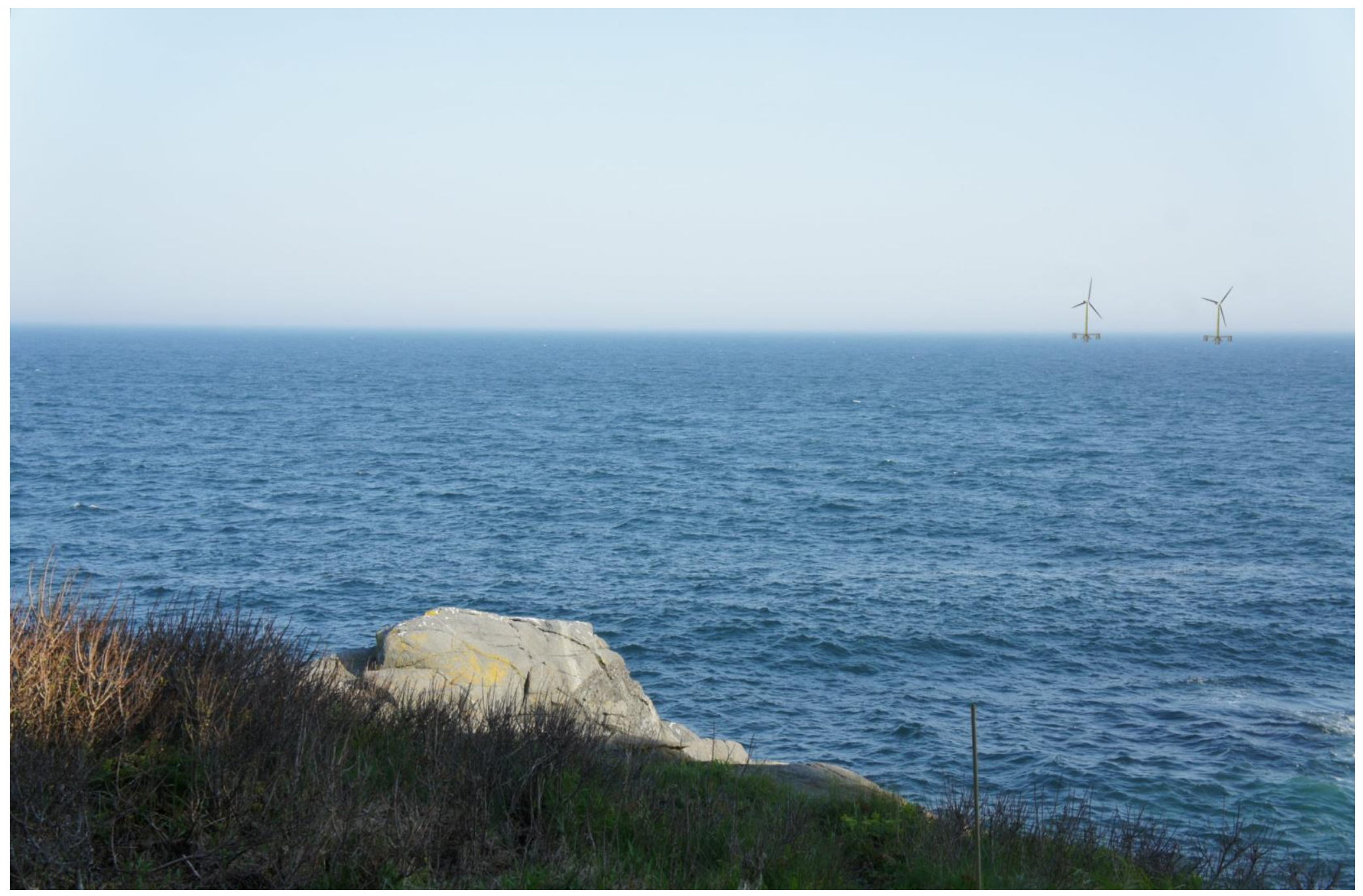

Picture 4. Taken by PNNL near Norton's Ledge; $43.756717^{\circ},-69.316050^{\circ} .80 \mathrm{ft}$. elevation facing due south $\left(180^{\circ}\right)$. Environmental conditions used to render Aqua Ventus I turbines were few clouds and light haze. 


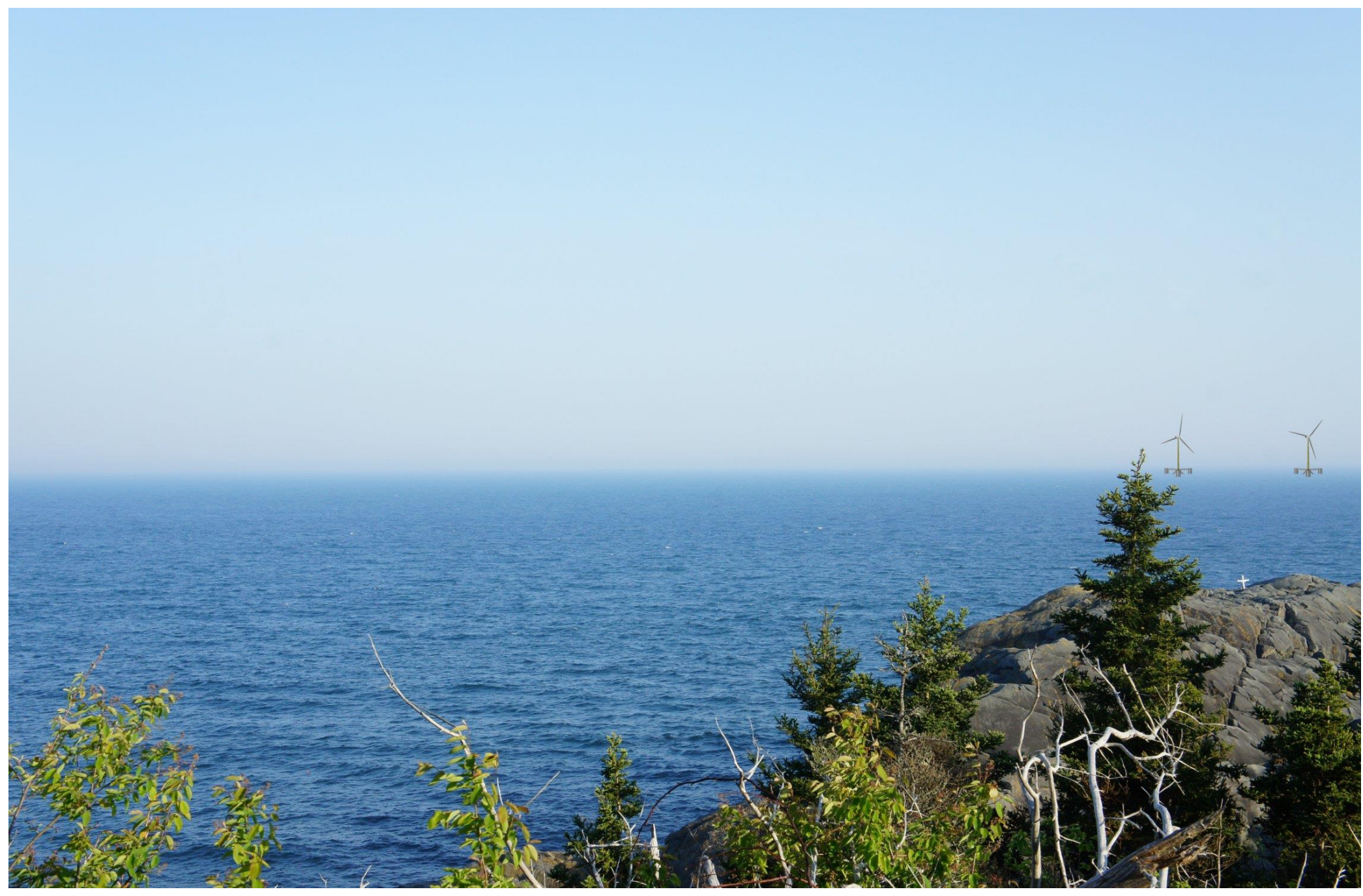

Picture 5. Taken by PNNL South of Burnt Head; $43.758633^{\circ},-69.314167^{\circ} .127 \mathrm{ft}$. elevation facing due south $\left(180^{\circ}\right)$. Environmental conditions used to render Aqua Ventus I turbines were partly cloudy and light haze. 


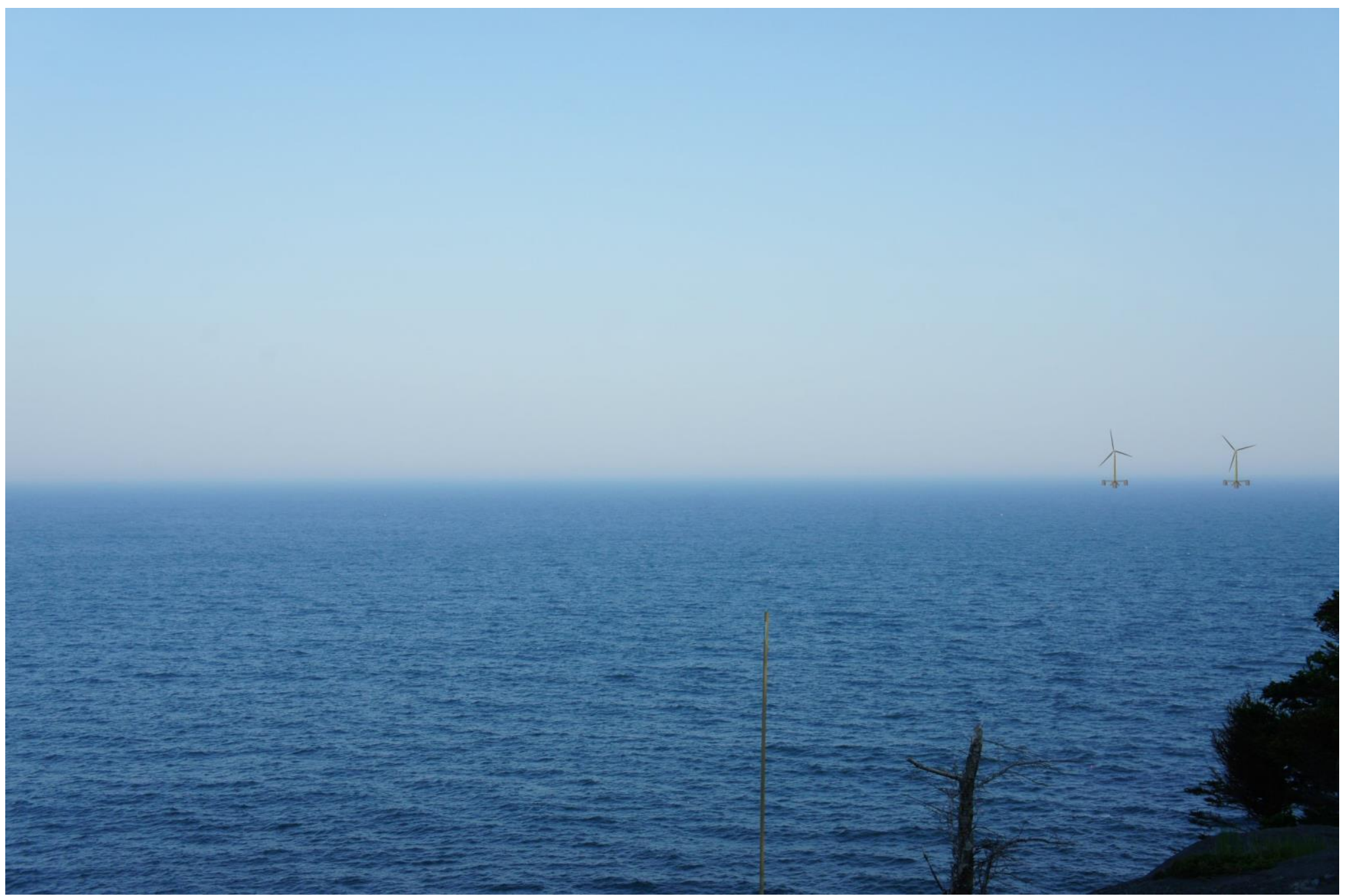

Picture 6. Taken by PNNL at Burnt Head; $43.759300^{\circ},-69.313617^{\circ} .153 \mathrm{ft}$. elevation facing due south $\left(180^{\circ}\right)$. Environmental conditions used to render Aqua Ventus I turbines were few clouds and light haze. 


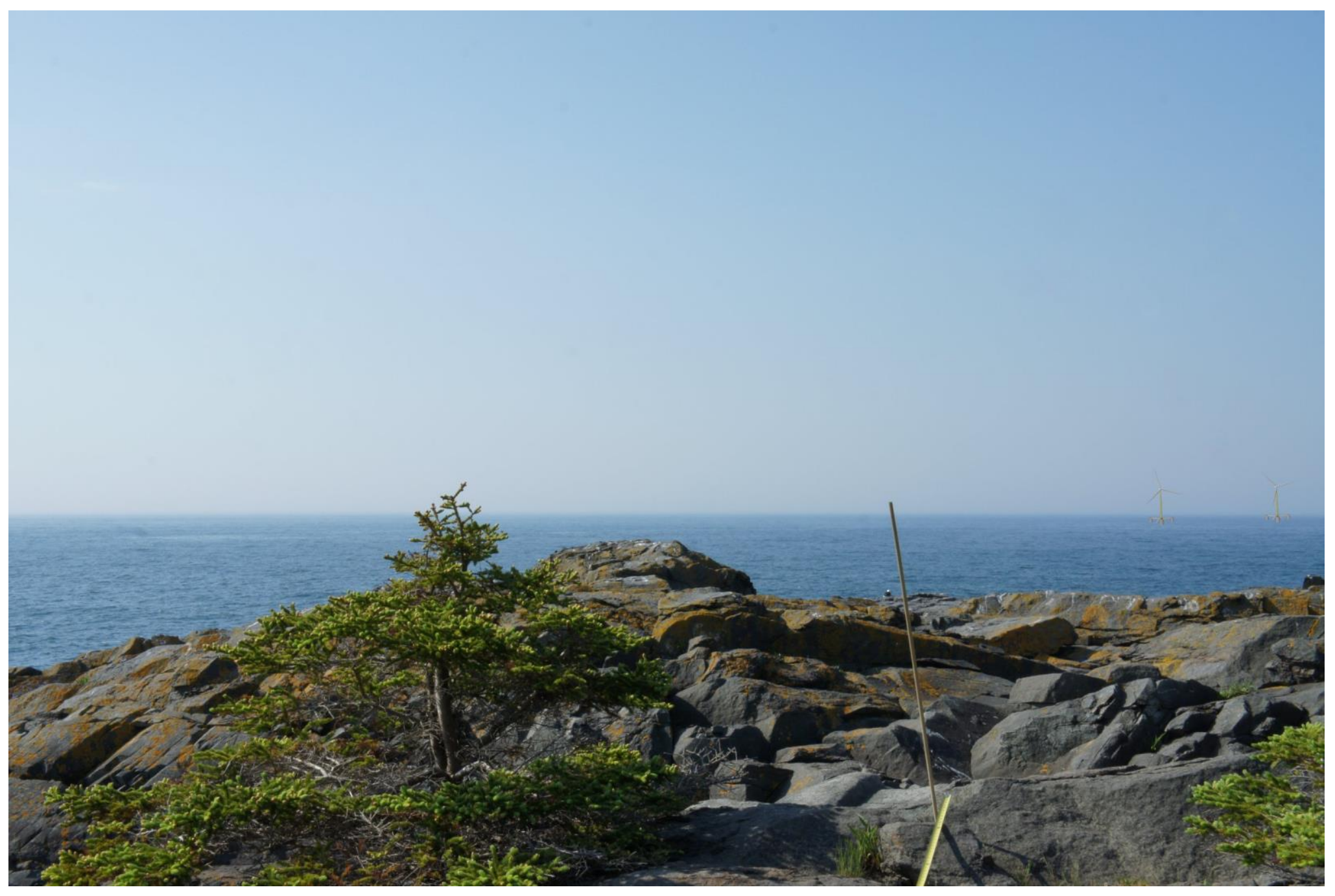

Picture 7. Taken by PNNL at Gull cove; $43.760950^{\circ},-69.311167^{\circ} .22 \mathrm{ft}$. elevation facing due south $\left(180^{\circ}\right)$. Environmental conditions used to render Aqua Ventus I turbines were few clouds and light haze. 


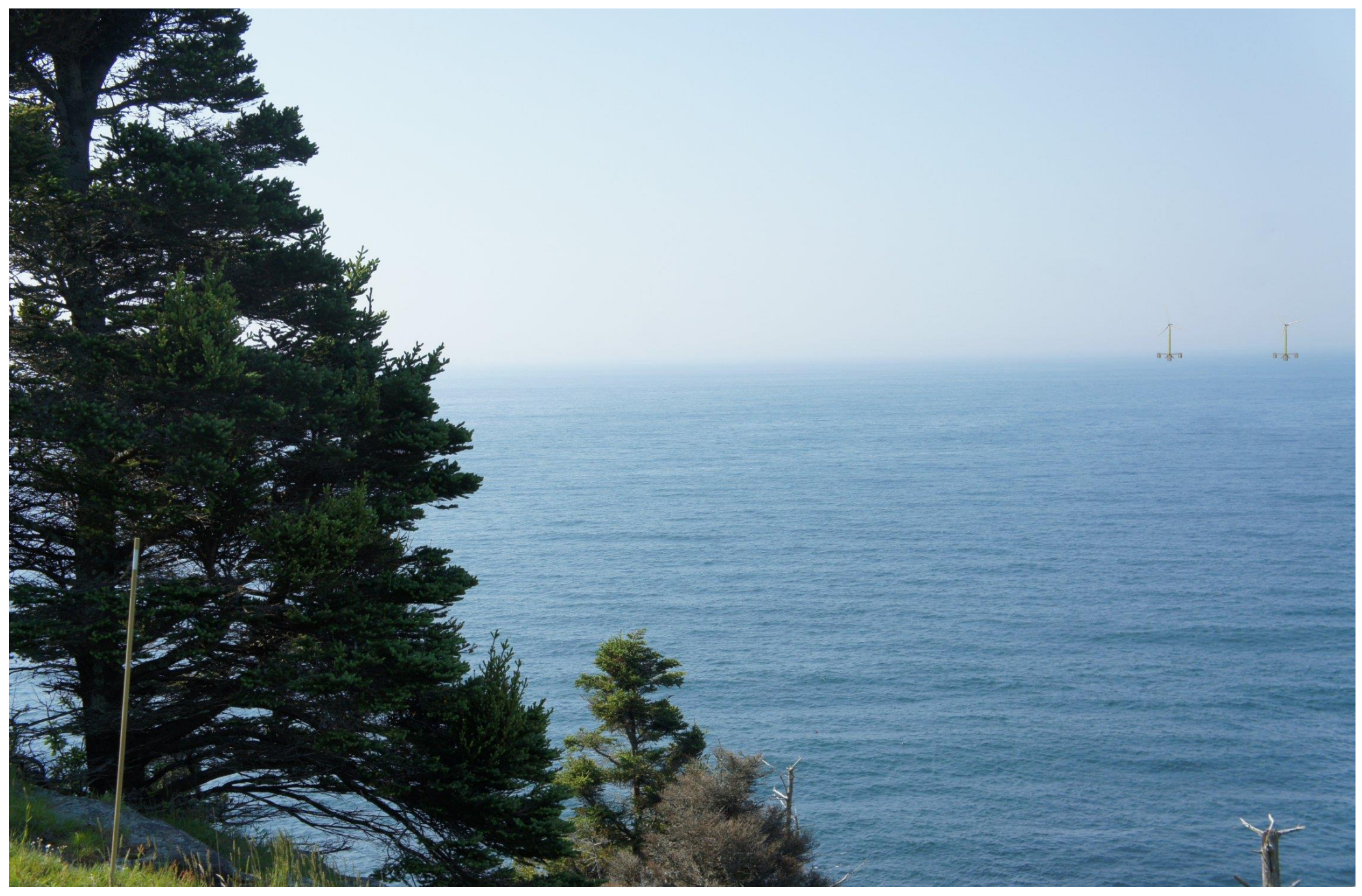

Picture 8. Taken by PNNL south of White Head; $43.762683^{\circ},-69.309367^{\circ} .130 \mathrm{ft}$. elevation facing due south $\left(180^{\circ}\right)$. Environmental conditions used to render Aqua Ventus I turbines were few clouds and light haze. 


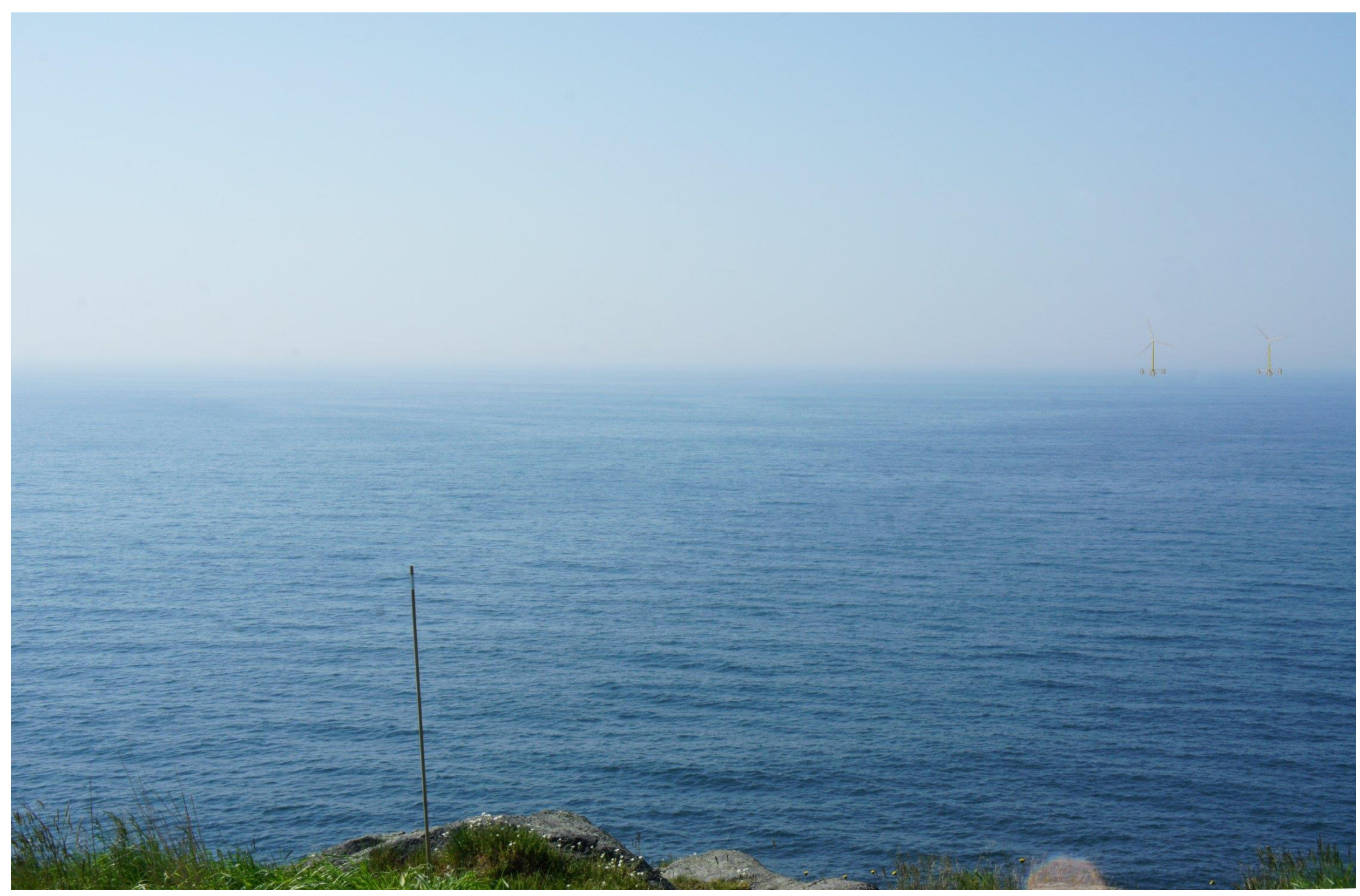

Picture 9. Taken by PNNL at White Head; $43.762187^{\circ},-69.309391^{\circ} .140 \mathrm{ft}$. elevation facing due south $\left(180^{\circ}\right)$. Environmental conditions used to render Aqua Ventus I turbines were few clouds and light haze. 


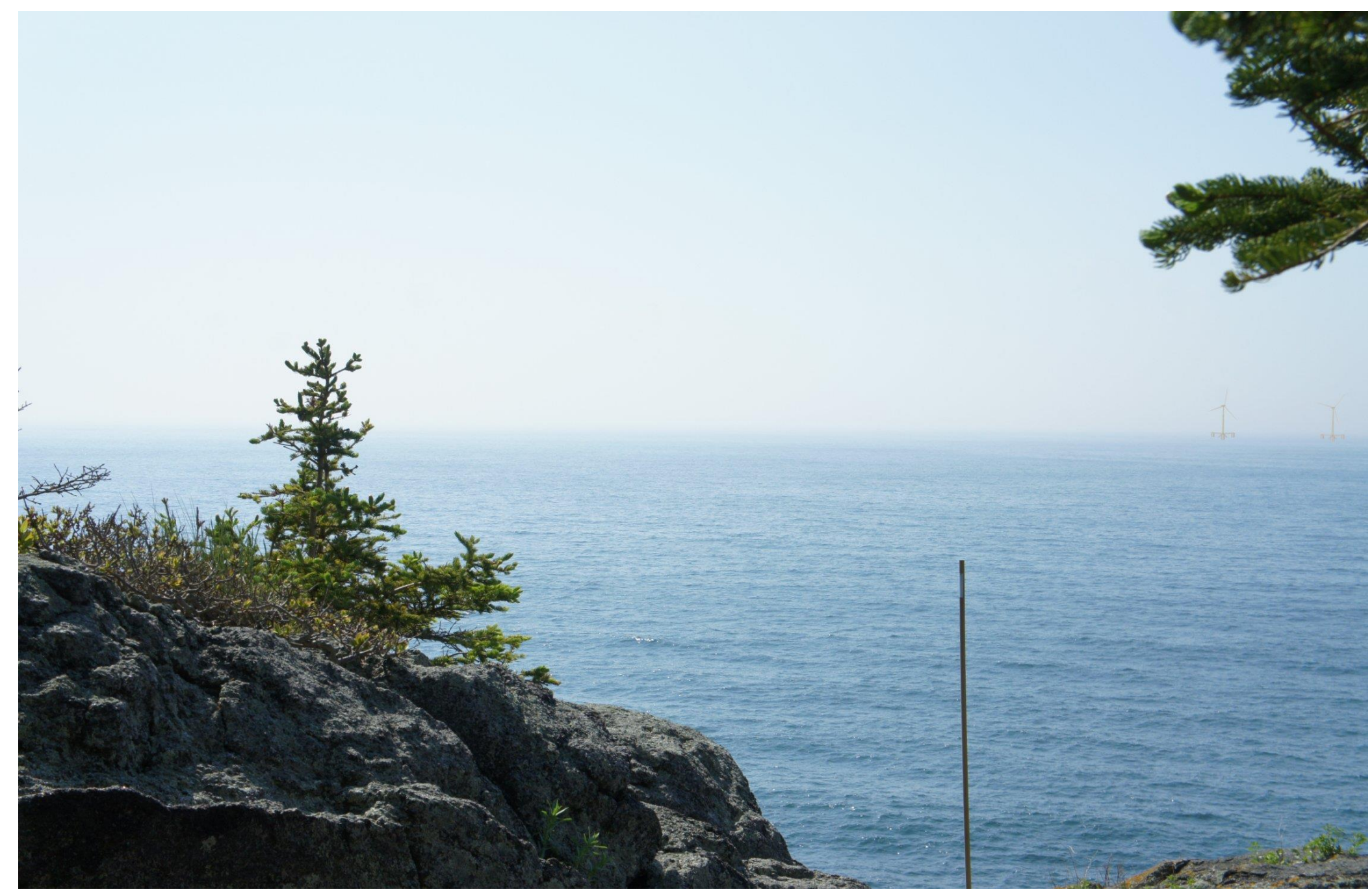

Picture 10. Taken by PNNL at Little White Head; $43.764783^{\circ},-69.306517^{\circ}$. $68 \mathrm{ft}$. elevation facing due south $\left(180^{\circ}\right)$. Environmental conditions used to render Aqua Ventus I turbines were clear sky and light haze. 


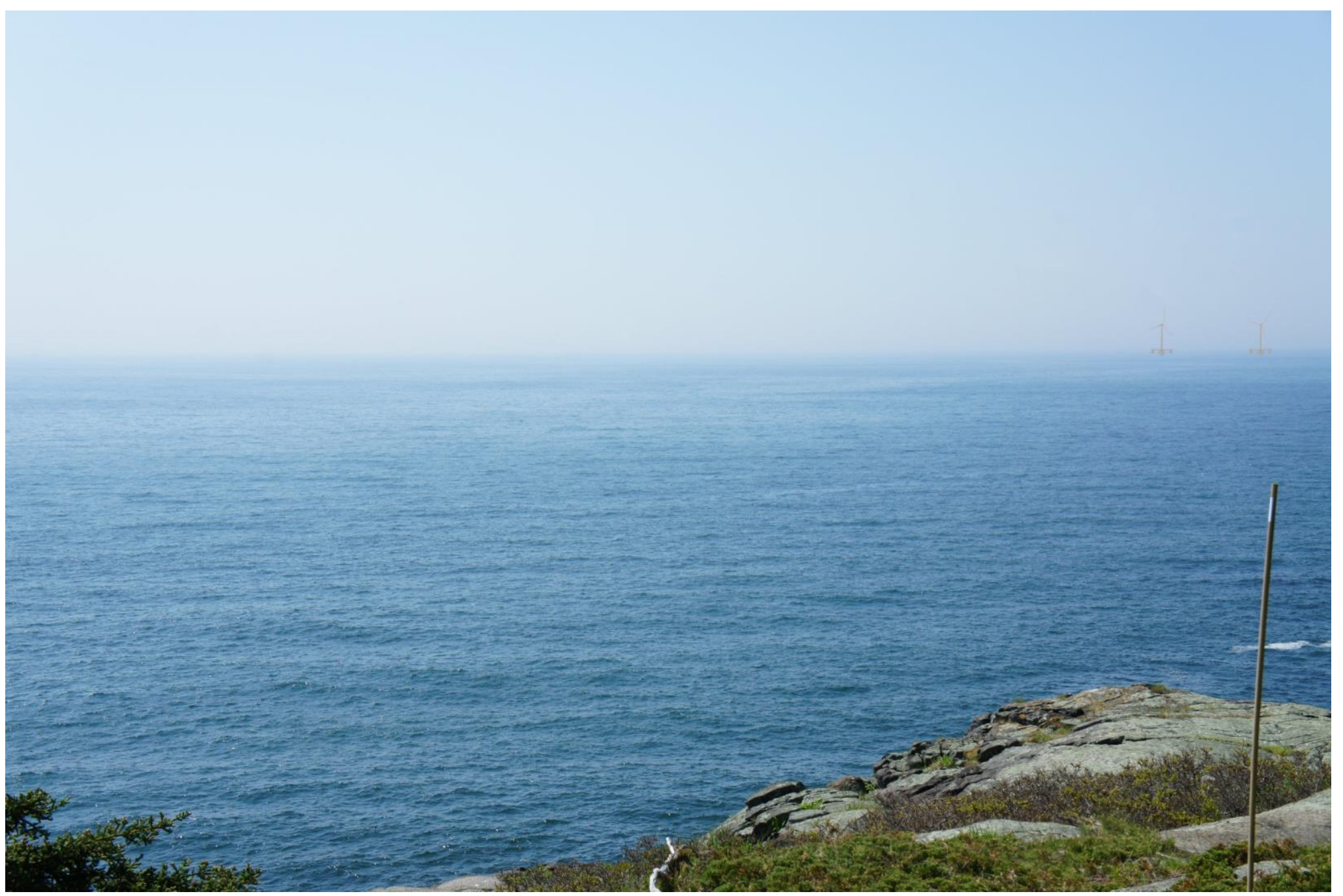

Picture 11. Taken by PNNL at Squeakers Cove; $43.767883^{\circ},-69.303800^{\circ}$. $67 \mathrm{ft}$. elevation facing due south $\left(180^{\circ}\right)$. Environmental conditions used to render Aqua Ventus I turbines were few clouds and fog. 


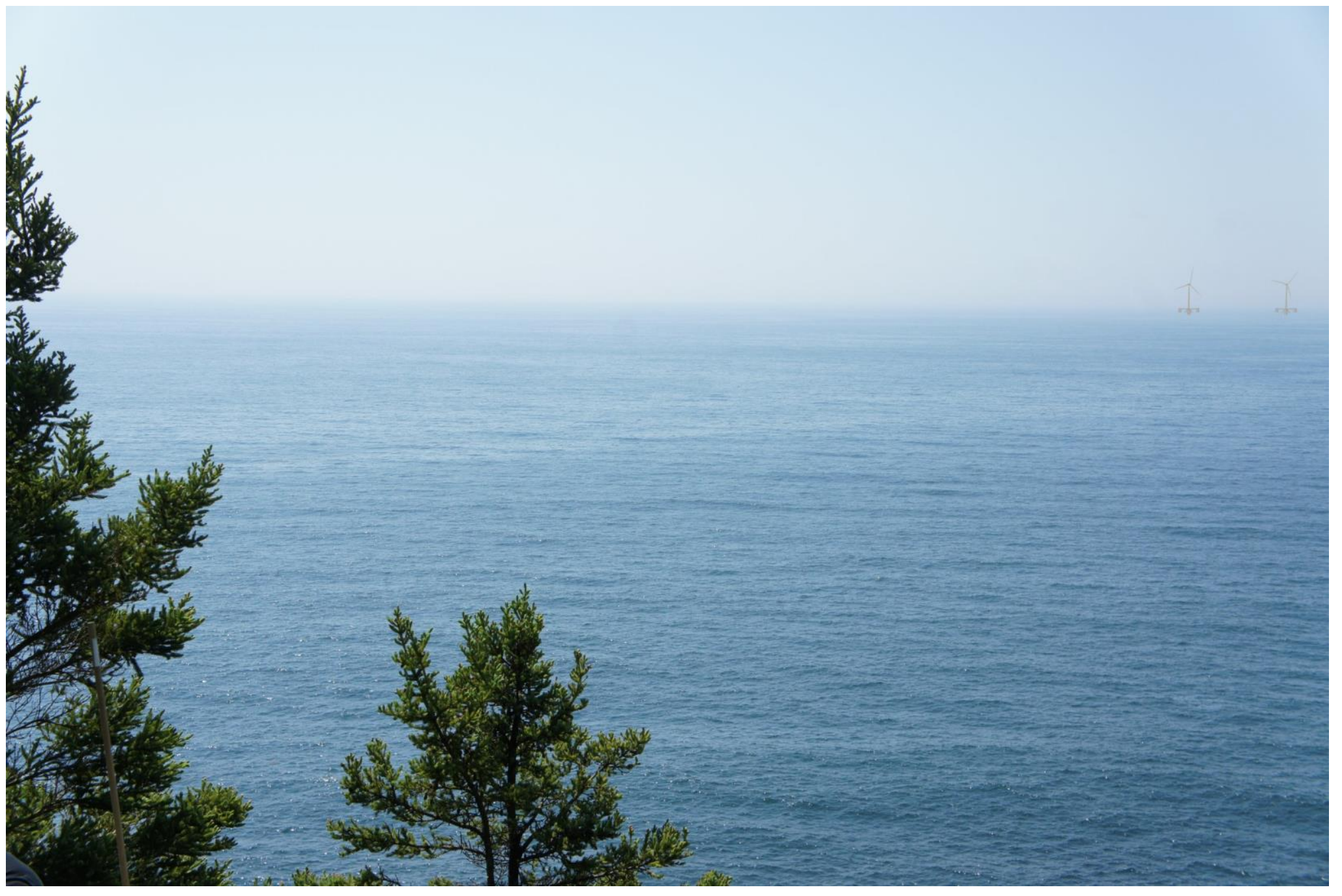

Picture 12. Taken by PNNL at Black Head; $43.768750^{\circ},-69.302667^{\circ} .127 \mathrm{ft}$. elevation facing due south $\left(180^{\circ}\right)$. Environmental conditions used to render Aqua Ventus I turbines were few clouds and fog. 


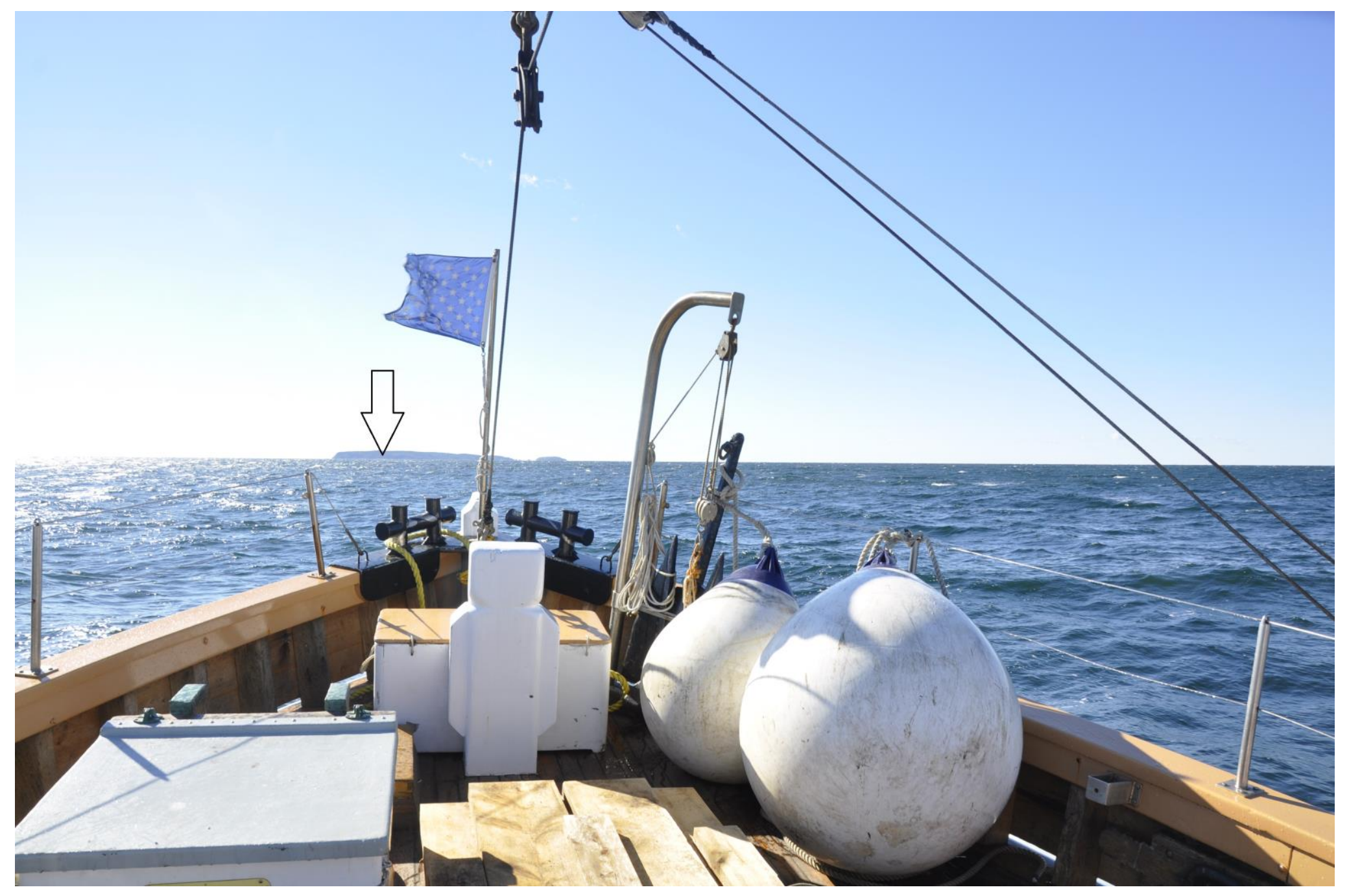

Picture 13. Taken by University of Maine, on ferry boat en route to Monhegan Island; $43.842778^{\circ},-69.283889^{\circ}$. Aqua Ventus I turbines located below arrow behind Monhegan Island. Picture was taken facing south/southwest $\left(210^{\circ}\right)$, elevation and environmental conditions used to render Aqua Ventus I turbines not available. 


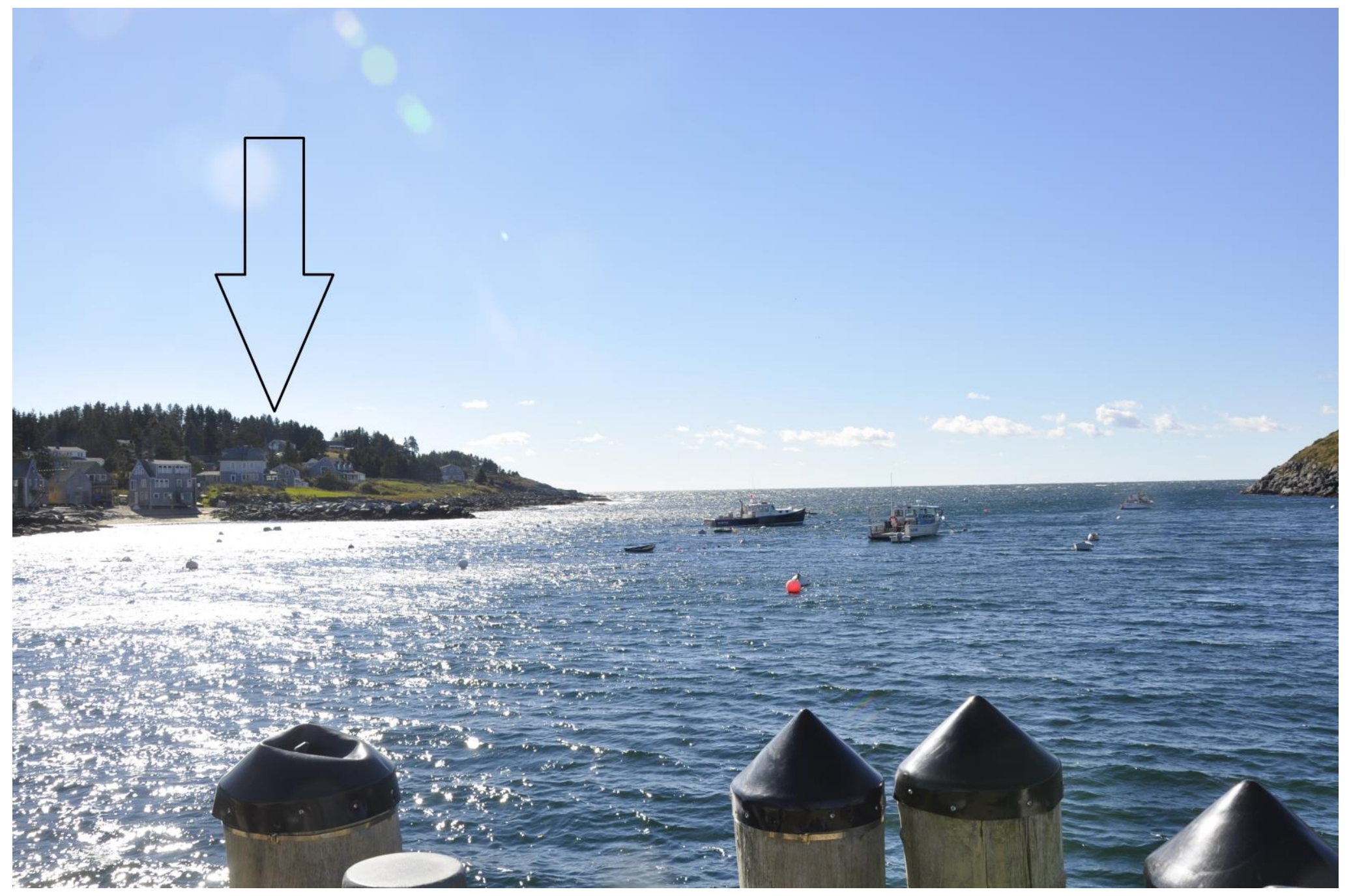

Picture 14. Taken by University of Maine at Monhegan wharf; $43.765060^{\circ},-69.321535^{\circ}$. Aqua Ventus I turbines located below arrow behind houses. Picture was taken facing south/southwest $\left(205^{\circ}\right)$, elevation and environmental conditions used to render Aqua Ventus I turbines not available. 


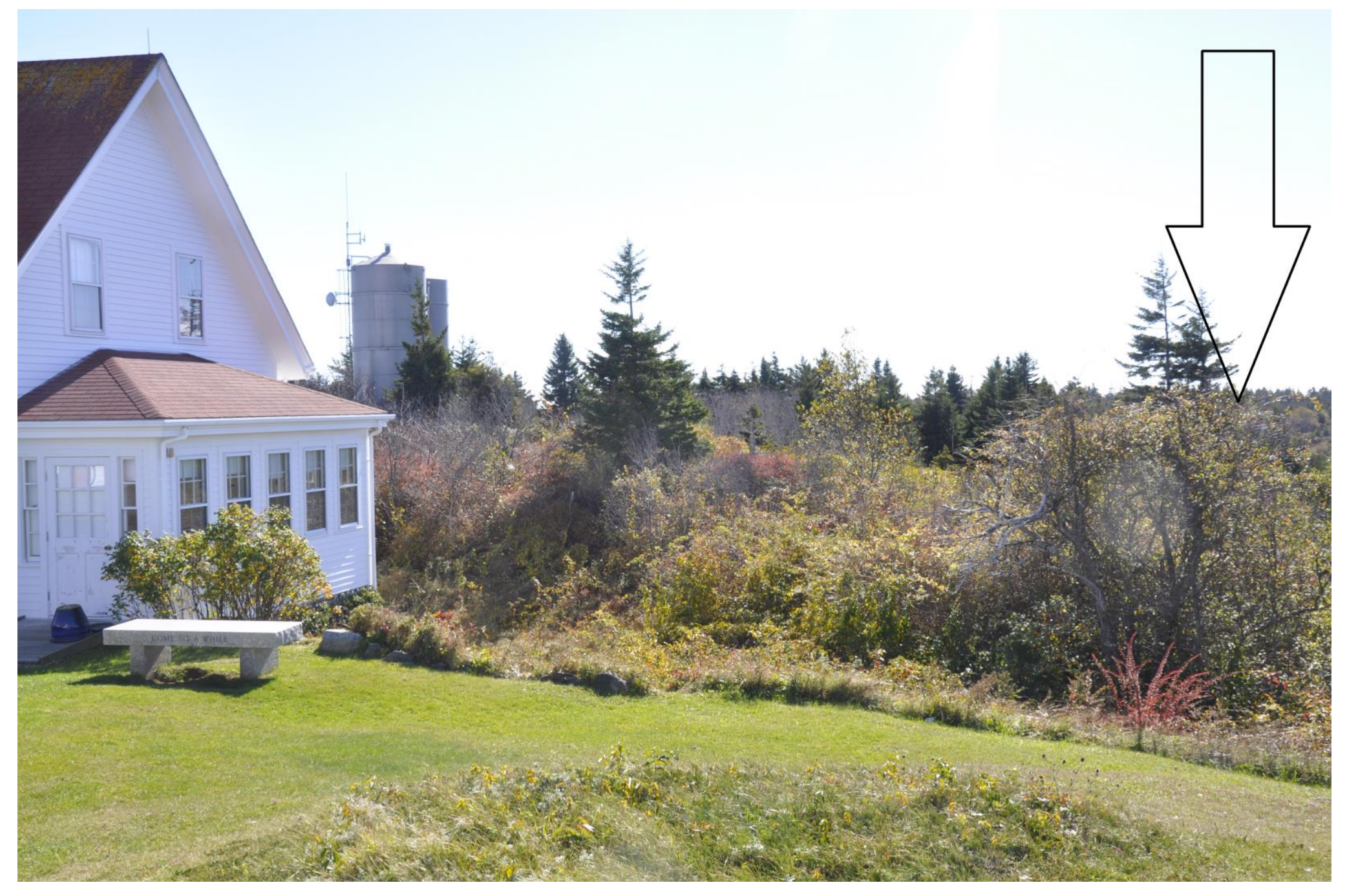

Picture 15. Taken by University of Maine at the Monhegan lighthouse bell; $43.764722^{\circ},-69.316111^{\circ}$. Aqua Ventus I turbines located below arrow behind trees. Picture was taken facing south/southeast $\left(169^{\circ}\right)$, elevation and environmental conditions used to render Aqua Ventus I turbines not available. 


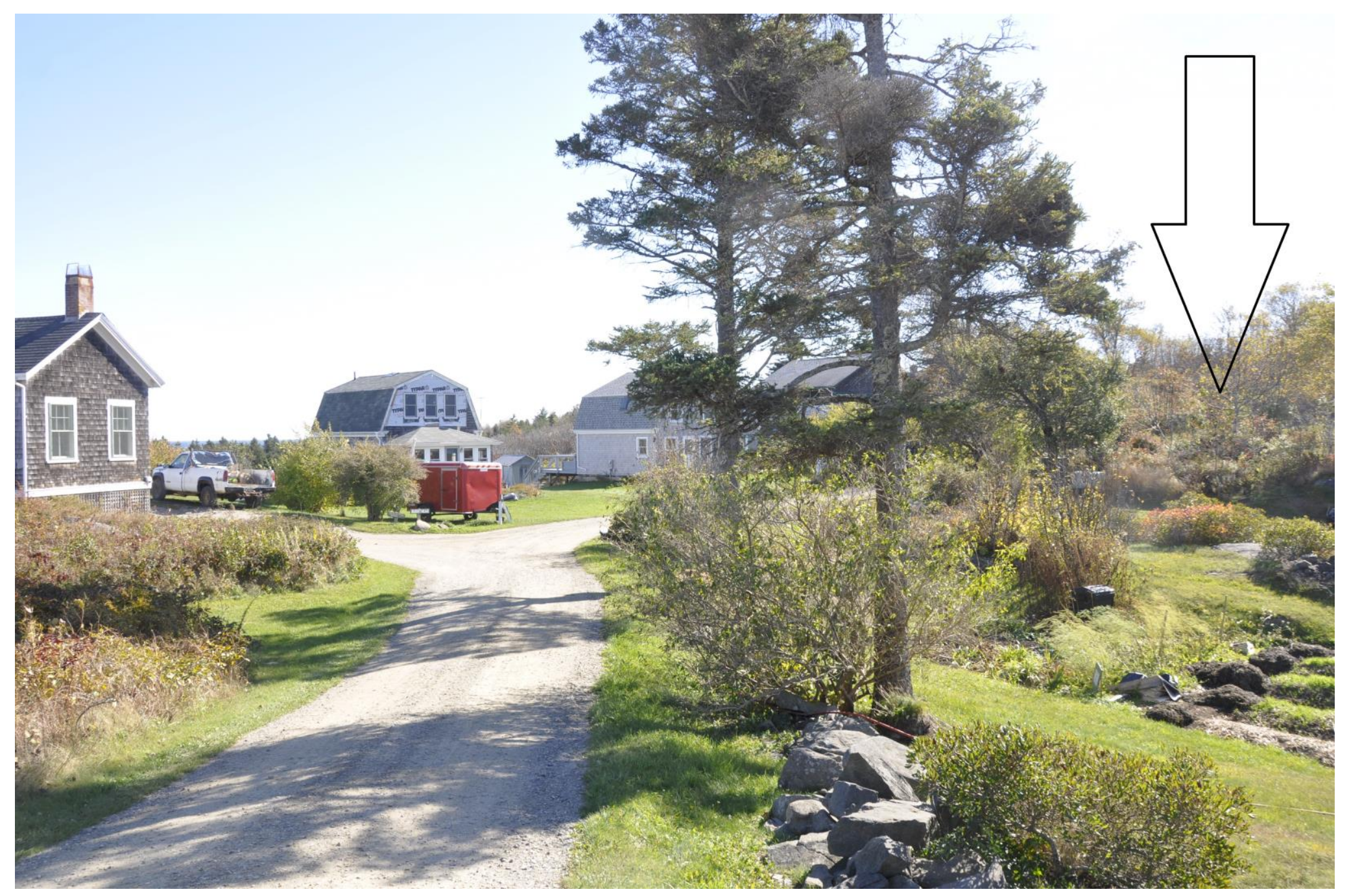

Picture 16. Taken by University of Maine at Horn Hill on Monhegan Island; $43.761944^{\circ},-69.317778^{\circ}$. Aqua Ventus I turbines located below arrow behind trees. Picture was taken facing south/southeast $\left(160^{\circ}\right)$, elevation and environmental conditions used to render Aqua Ventus I turbines not available. 


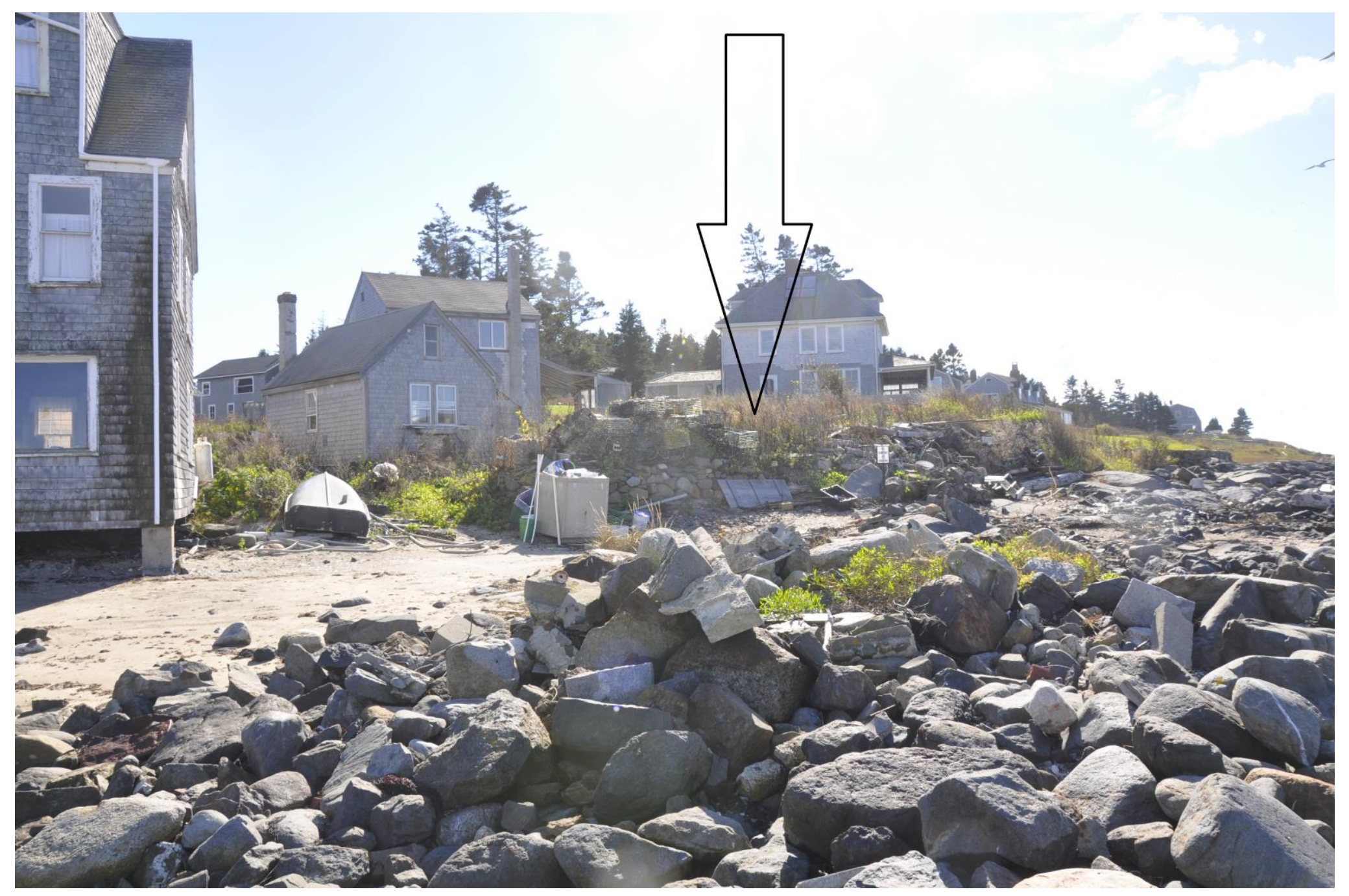

Picture 17. Taken by University of Maine at Fish Beach on Monhegan Island; $43.763056^{\circ},-69.321667^{\circ}$. Aqua Ventus I turbines located below arrow behind trees. Picture was taken facing south $\left(180^{\circ}\right)$, elevation and environmental conditions used to render Aqua Ventus I turbines not available. 


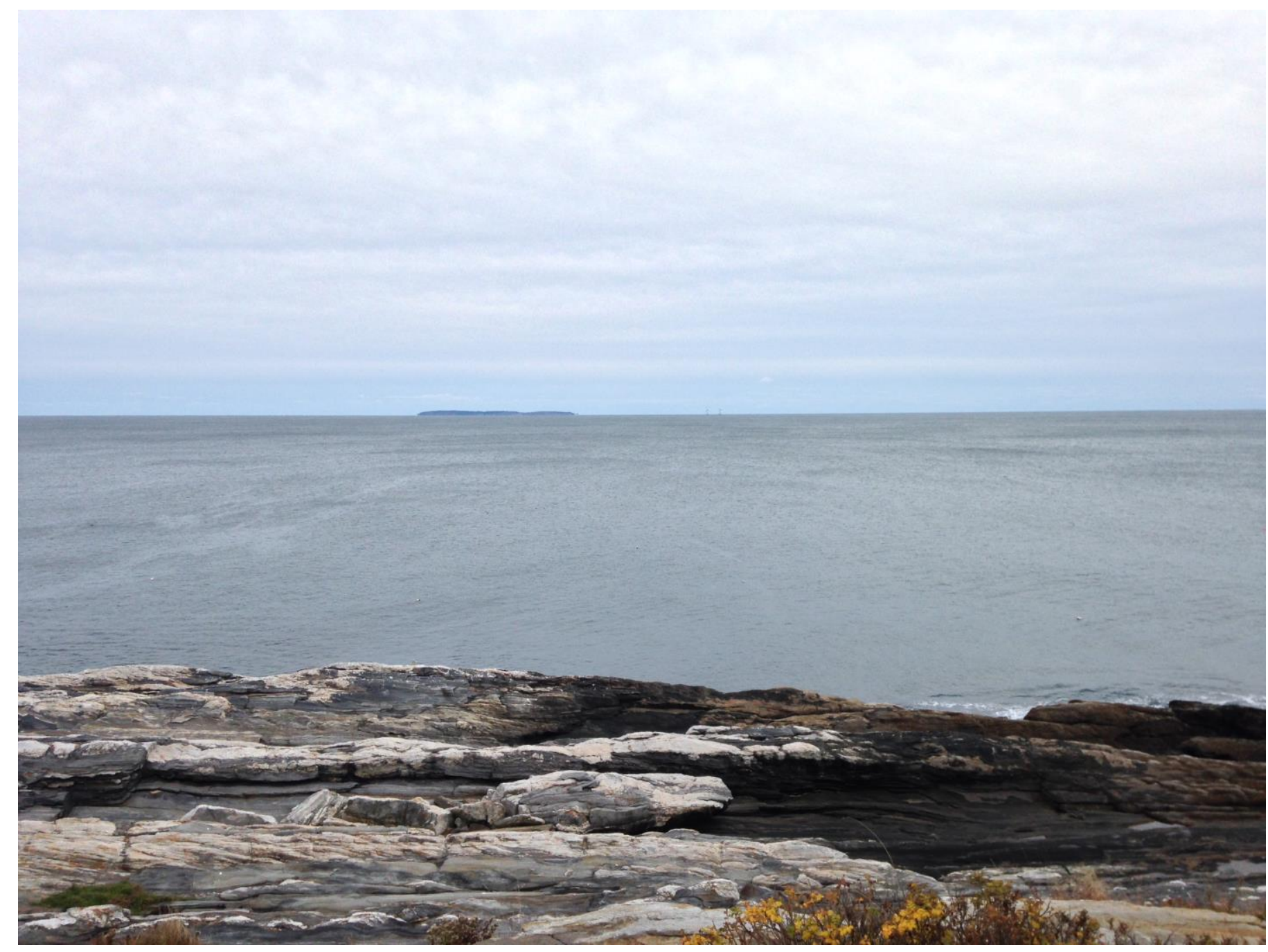

Picture 18. Taken by University of Maine at Pemaquid Point (mainland); $43.837222^{\circ},-69.506111^{\circ}$. Aqua Ventus I turbines located just to the right of Monhegan Island. Picture was taken facing southeast $\left(149^{\circ}\right)$, elevation and environmental conditions used to render Aqua Ventus I turbines not available. 


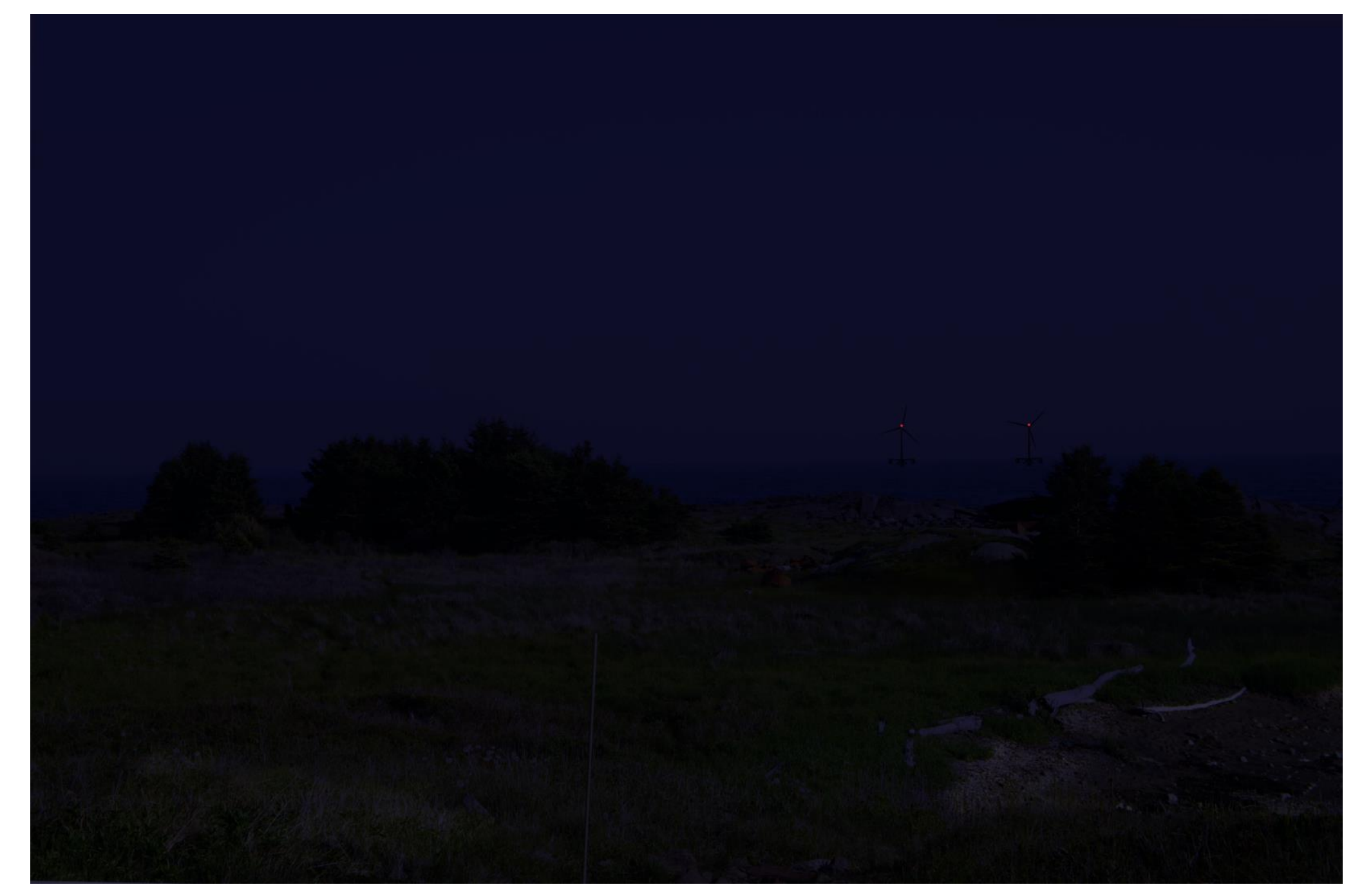

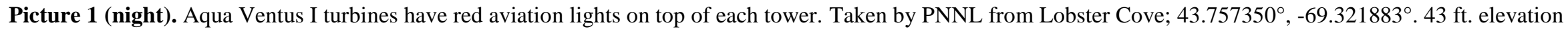
facing due south $\left(180^{\circ}\right)$. 


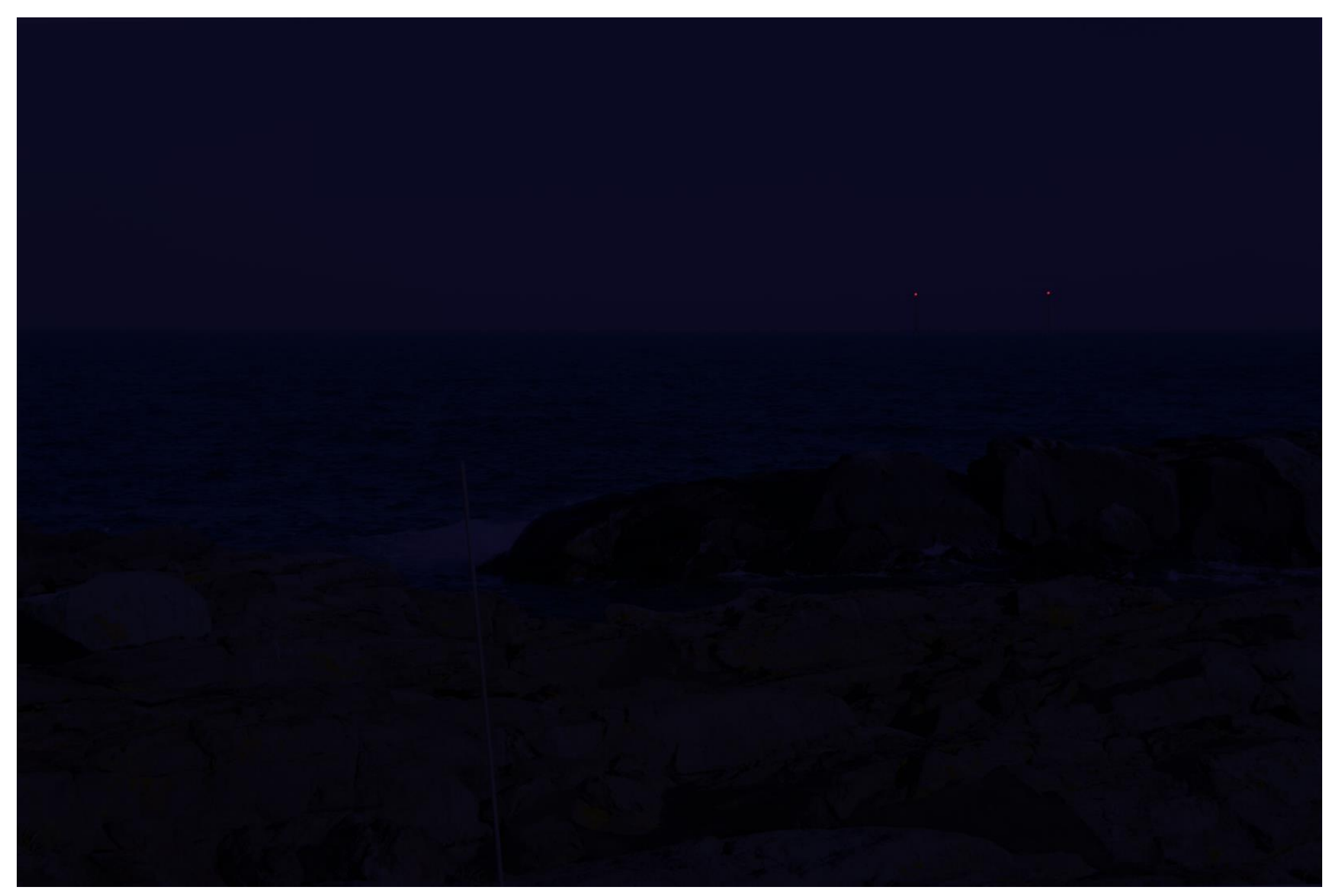

Picture 2 (night). Aqua Ventus I turbines have red aviation lights on top of each tower. Taken by PNNL from Christmas Cove; $43.755817^{\circ},-69.320817^{\circ} .40 \mathrm{ft}$. elevation facing due south $\left(180^{\circ}\right)$. 
Picture 3 (night). Aqua Ventus I turbines have red aviation lights on top of each tower. Taken by PNNL between Christmas Cove and Norton's Ledge; $43.756300^{\circ}$, $69.319483^{\circ} .80 \mathrm{ft}$. elevation facing due south $\left(180^{\circ}\right)$. 
Picture 4 (night). Aqua Ventus I turbines have red aviation lights on top of each tower. Taken by PNNL near Norton’s Ledge; $43.756717^{\circ},-69.316050^{\circ}$. $80 \mathrm{ft}$. elevation facing due south $\left(180^{\circ}\right)$. 
Picture 5 (night). Aqua Ventus I turbines have red aviation lights on top of each tower. Taken by PNNL South of Burnt Head; $43.758633^{\circ},-69.314167^{\circ} .127 \mathrm{ft}$. elevation facing due south $\left(180^{\circ}\right)$. 


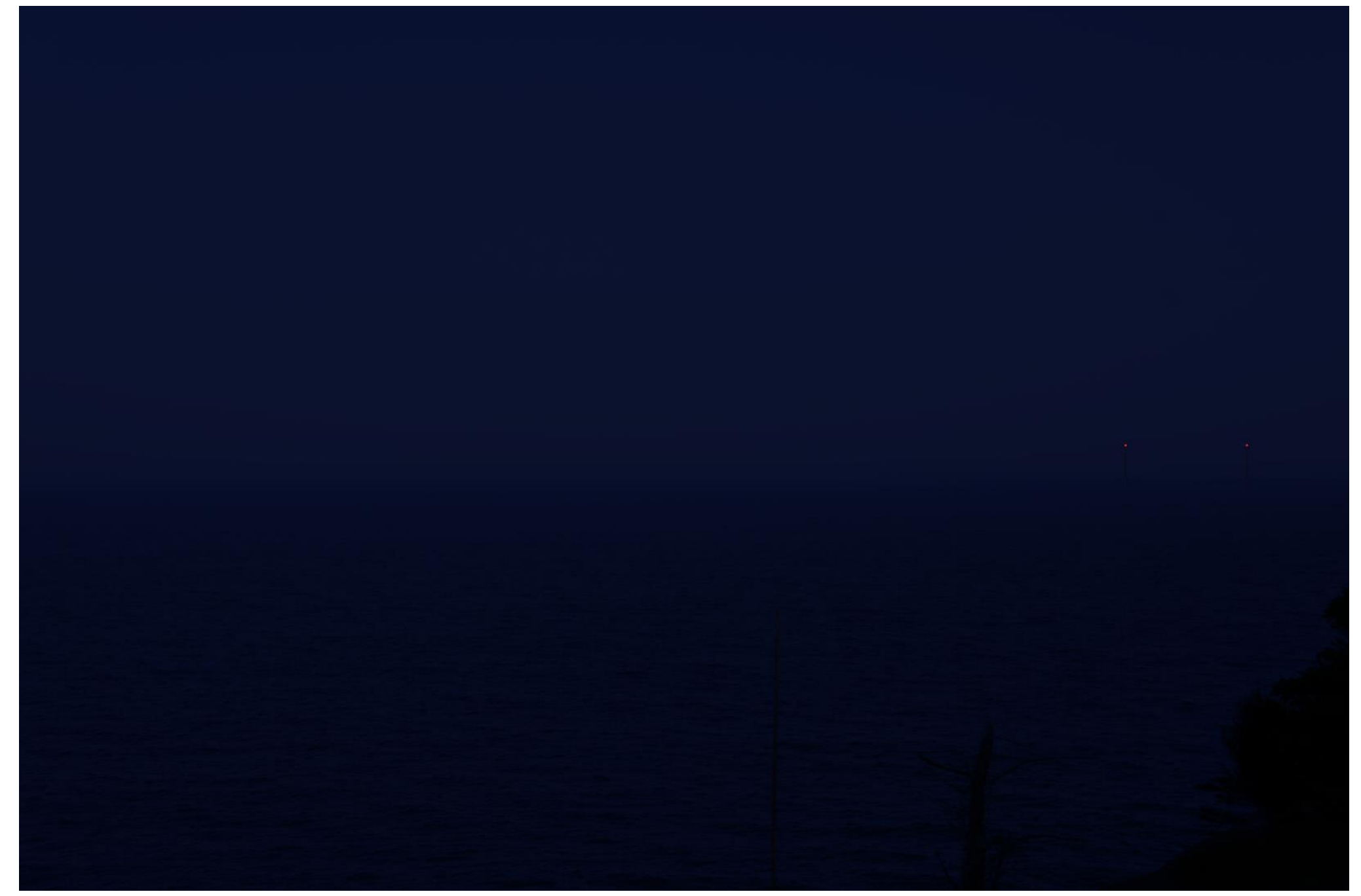

Picture 6 (night). Aqua Ventus I turbines have red aviation lights on top of each tower. Taken by PNNL at Burnt Head; $43.759300^{\circ}$, $-69.313617^{\circ}$. $153 \mathrm{ft}$. elevation facing due south $\left(180^{\circ}\right)$. 


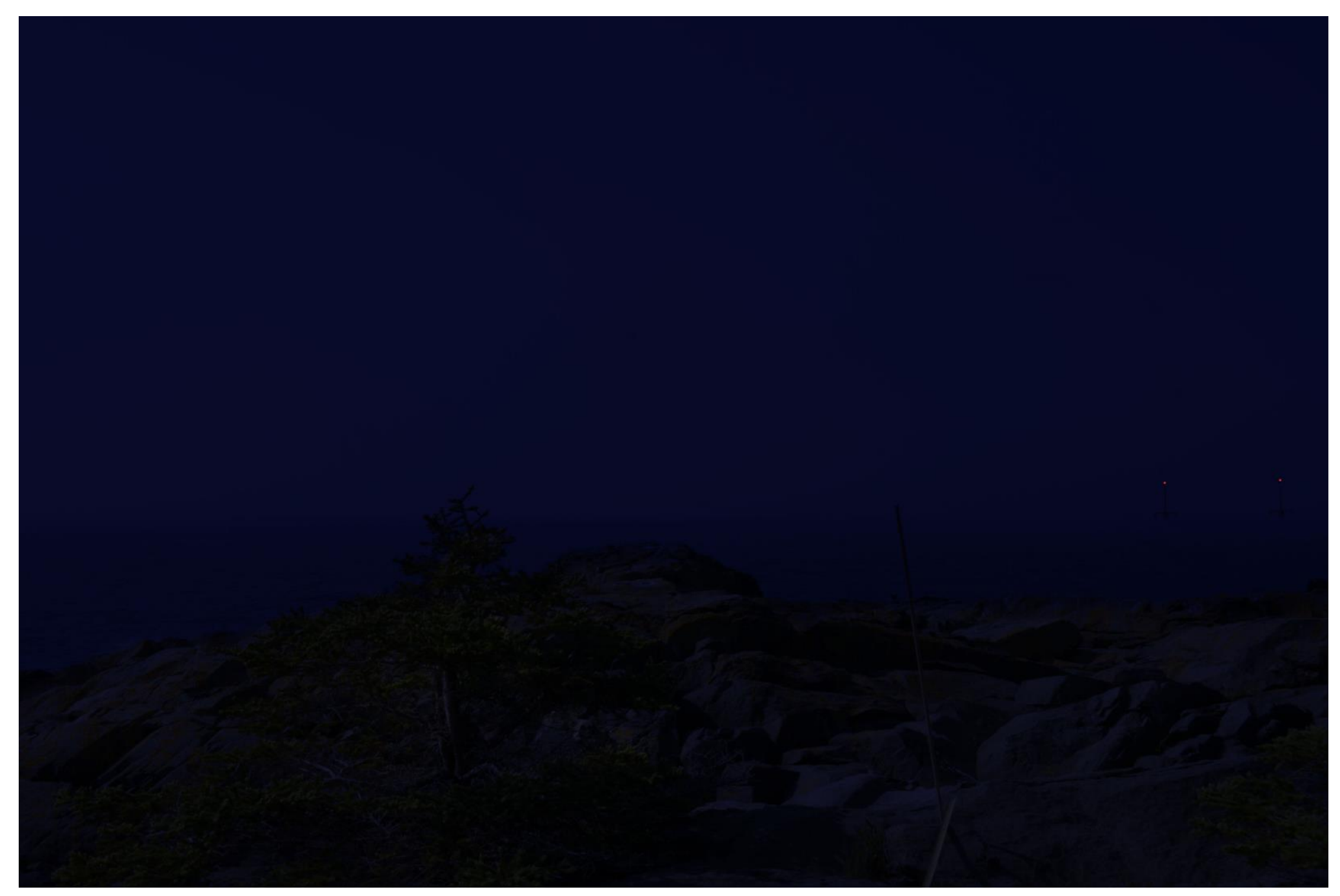

Picture 7 (night). Aqua Ventus I turbines have red aviation lights on top of each tower. Taken by PNNL at Gull cove; $43.760950^{\circ},-69.311167^{\circ} .22 \mathrm{ft}$. elevation facing due south $\left(180^{\circ}\right)$. 


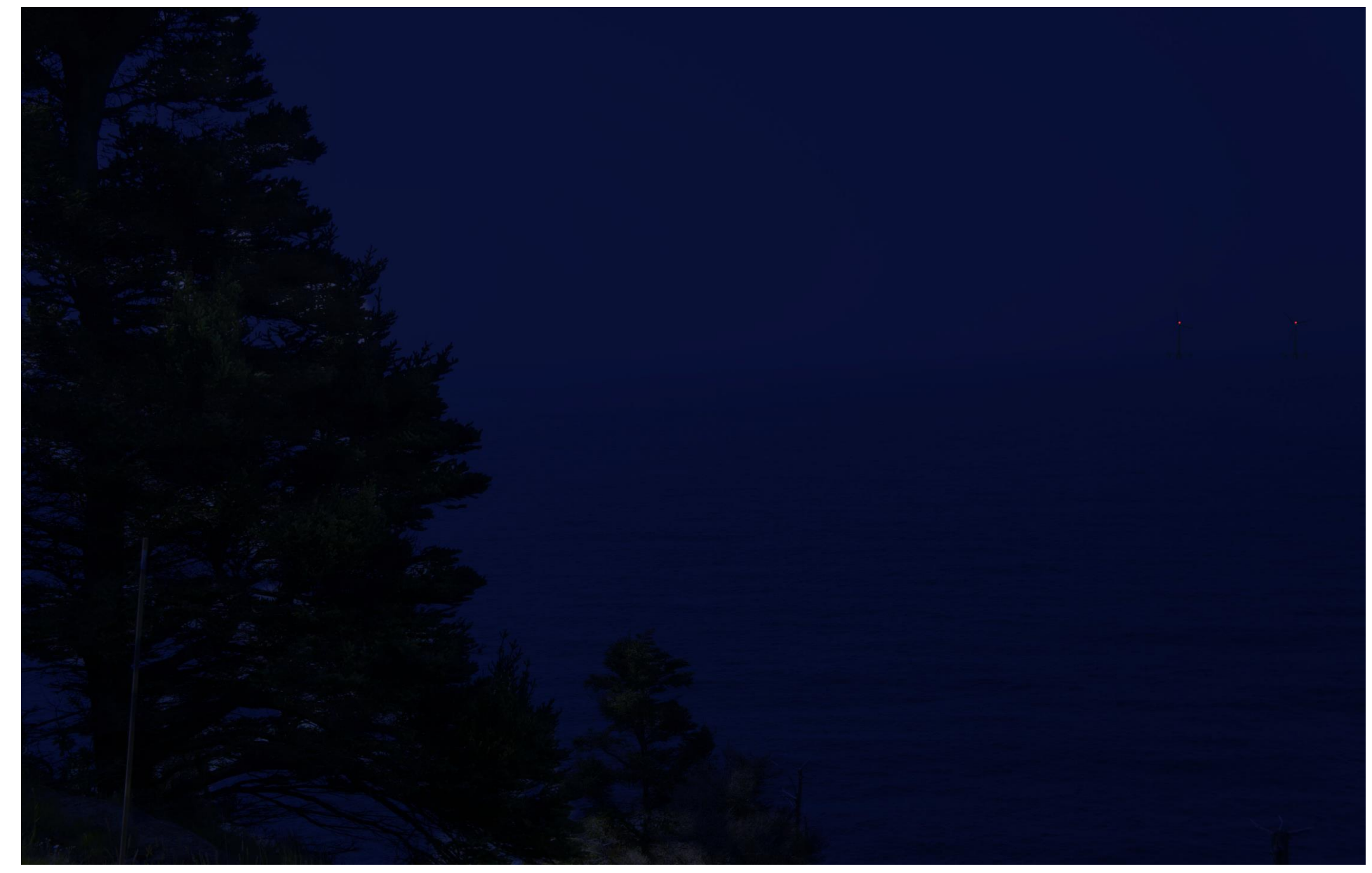

Picture 8 (night). Aqua Ventus I turbines have red aviation lights on top of each tower. Taken by PNNL south of White Head; $43.762683^{\circ},-69.309367^{\circ}$. $130 \mathrm{ft}$. elevation facing due south $\left(180^{\circ}\right)$. 


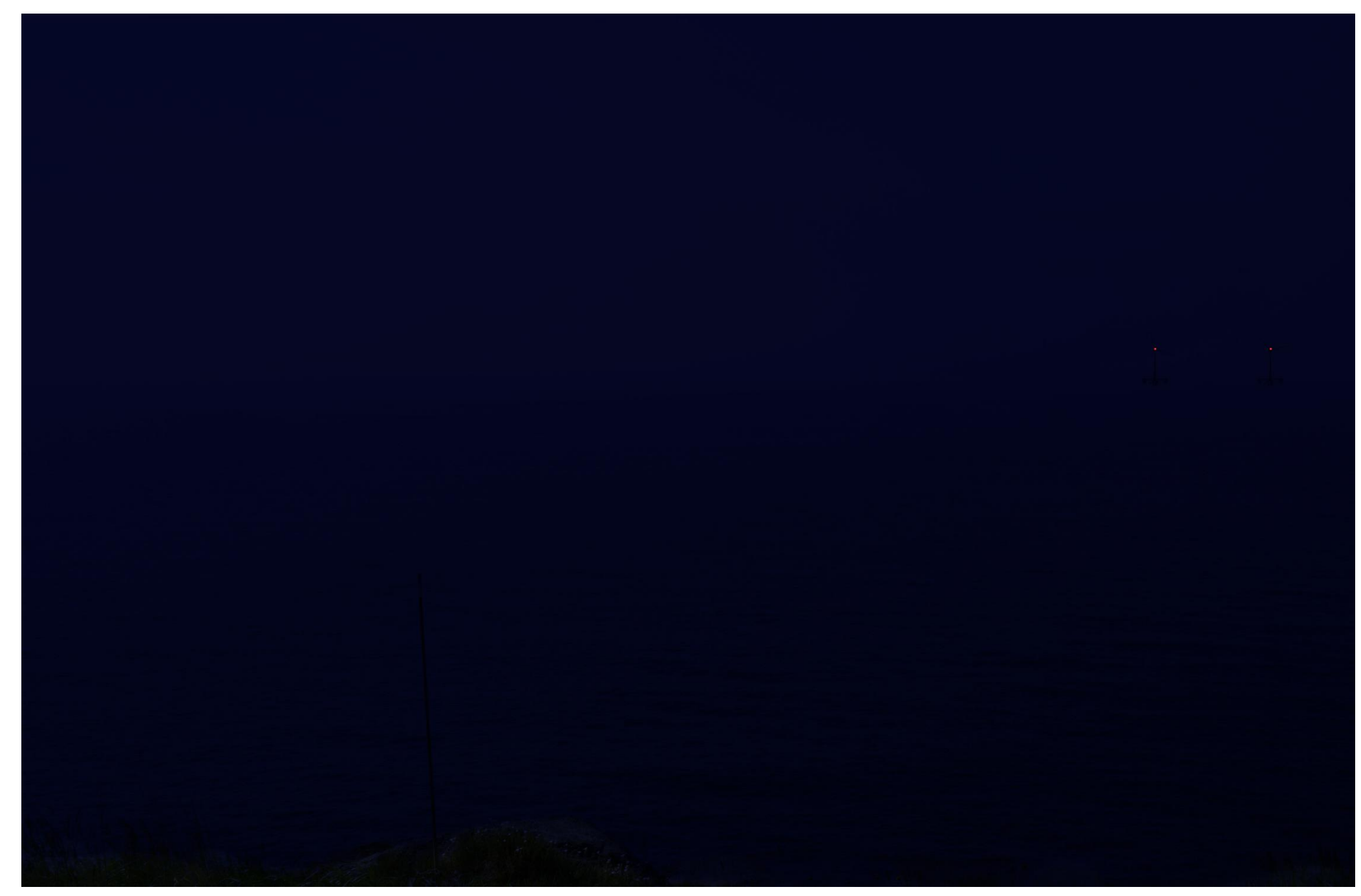

Picture 9 (night). Aqua Ventus I turbines have red aviation lights on top of each tower. Taken by PNNL at White Head; $43.762187^{\circ}$, $-69.309391^{\circ}$. $140 \mathrm{ft}$. elevation facing due south $\left(180^{\circ}\right)$. 
Picture 10 (night). Aqua Ventus I turbines have red aviation lights on top of each tower. Taken by PNNL at Little White Head; $43.764783^{\circ},-69.306517^{\circ} .68 \mathrm{ft}$. elevation facing due south $\left(180^{\circ}\right)$. 


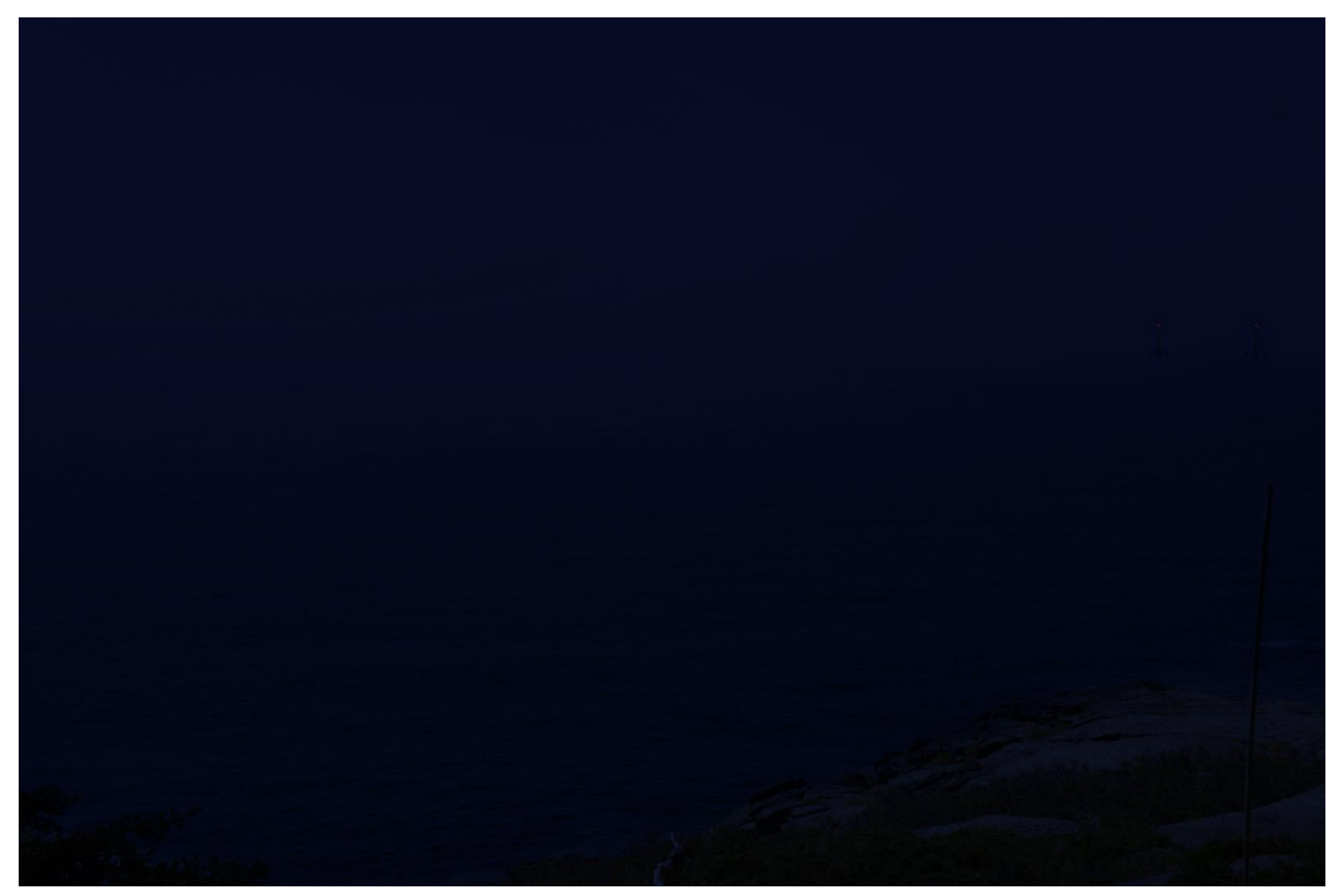

Picture 11 (night). Aqua Ventus I turbines have red aviation lights on top of each tower. Taken by PNNL at Squeakers Cove; $43.767883^{\circ},-69.303800^{\circ} .67 \mathrm{ft}$. elevation facing due south $\left(180^{\circ}\right)$. 


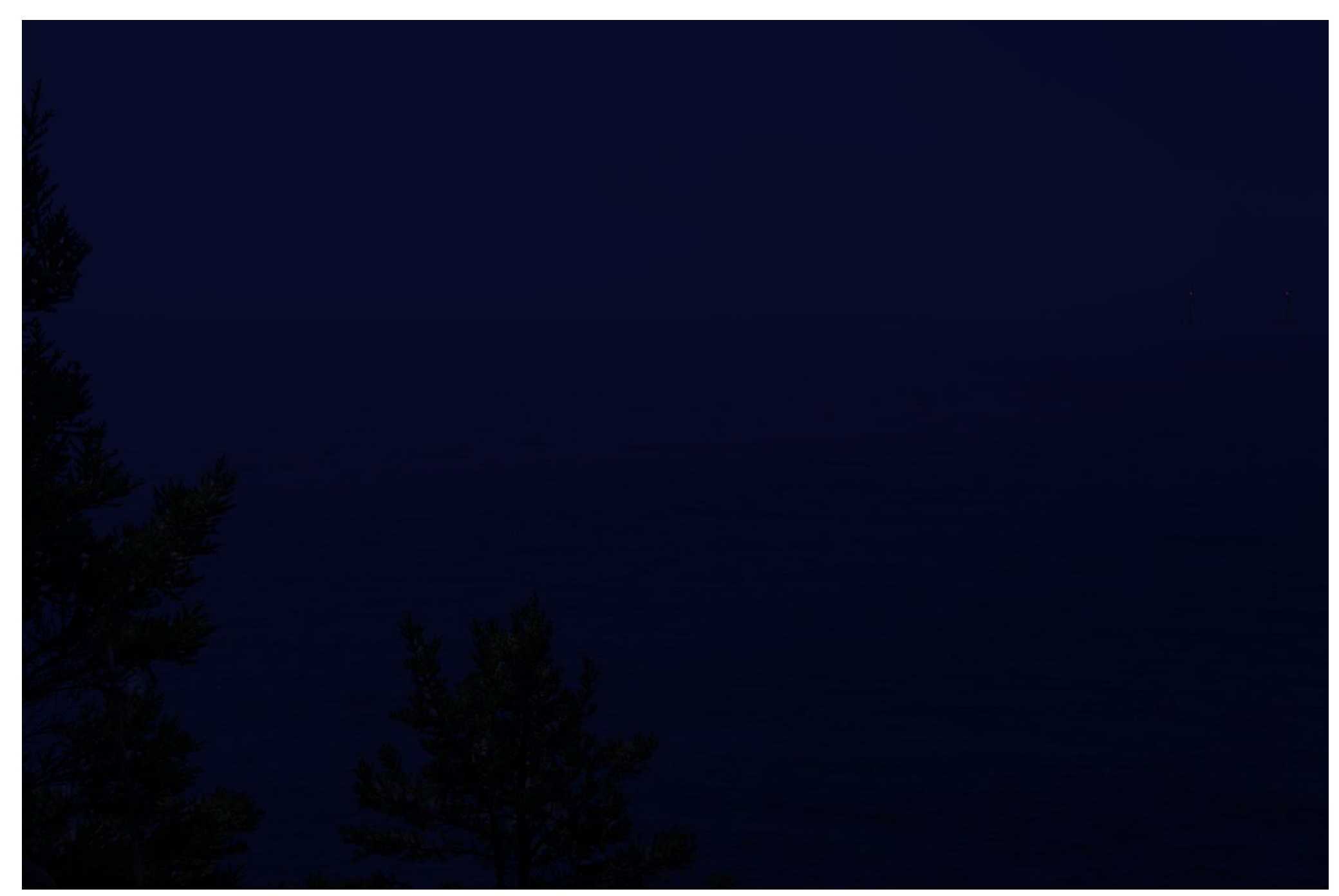

Picture 12 (night). Aqua Ventus I turbines have red aviation lights on top of each tower. Taken by PNNL at Black Head; $43.768750^{\circ},-69.302667^{\circ} .127 \mathrm{ft}$. elevation facing due south $\left(180^{\circ}\right)$. 


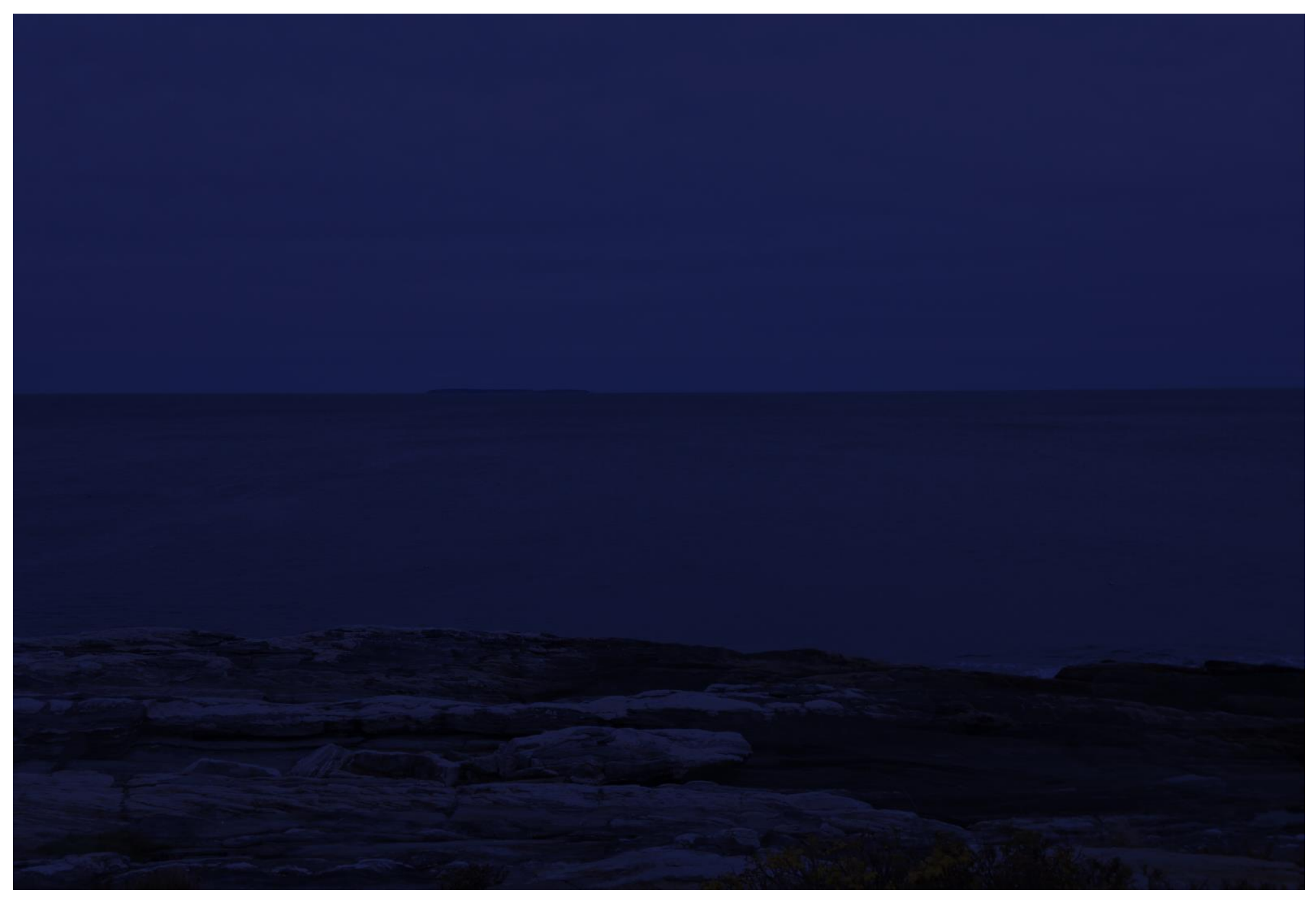

Picture 18 (night). Aqua Ventus I turbines have red aviation lights on top of each tower. Taken by University of Maine at Pemaquid Point (mainland); $43.837222^{\circ},-$ $69.506111^{\circ}$. Picture was taken facing southeast $\left(149^{\circ}\right)$. 


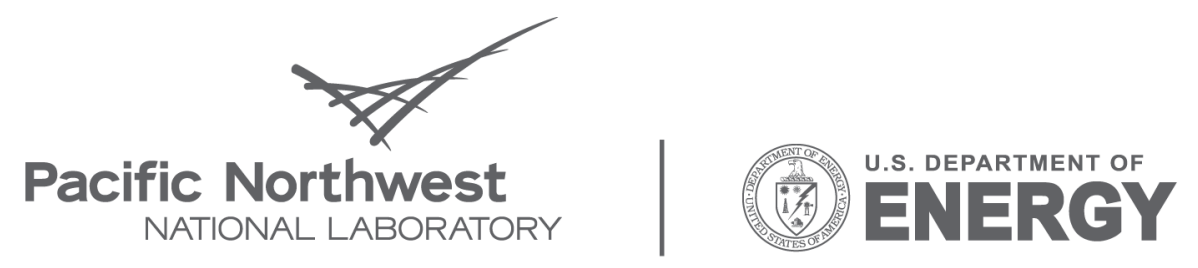

Proudly Operated by Battelle Since 1965

902 Battelle Boulevard

P.O. Box 999

Richland, WA 99352

1-888-375-PNNL (7665)

www.pnl.gov 